\title{
Czy tylko prometeizm? Polityka państwa polskiego wobec wybranych kół emigracji rosyjskiej w latach 1926-1935
}

Zarys treści: Autor artykułu stawia sobie za zadnie przeanalizowanie polityki władz polskich wobec emigrantów rosyjskich przebywających w Polsce, w latach 1926-1935 i znalezienie odpowiedzi na pytanie, na ile polityka ta różniła się od polityki prowadzonej we wcześniejszym okresie. Odpowiada również na pytanie, jakie były przyczyny zainteresowania władz polskich Rosjanami w kontekście polityki prometejskiej.

Outline of content: The author sets himself a task of analysing policy of the Polish authorities towards the Russian emigrants in Poland in 1926-1935 and of answering the question in which way that policy differed from the one pursued in the earlier period. He also answers the question of what caused the interest of the Polish authorities in the Russians in the context of Promethean policy.

Słowa kluczowe: II Rzeczpospolita, Sawinkow, Piłsudski, Fiłosofow, Niezbrzycki, wywiad, prometeizm

Keywords: Second Republic of Poland, Savinkov, Pilsudski, Filosofov, Niezbrzycki, intelligence, Prometheism

„Bezinteresowni i życzliwi..., czy są tacy na Zachodzie? Dużą pomoc, bez stawiania jakichkolwiek warunków, zdecydowała się okazać w tym czasie NTSNP Polska. Dozgonna jej wdzięczność. Współpraca z Polakami przed wojną, dała podstawę do współpracy w czasie wojny" ${ }^{1}$. W tych dość patetycznych słowach dziękował Polakom, czterdzieści lat po wojnie, Arkadiusz Stołypin, członek kierownictwa

\footnotetext{
1 А.П. Столыпин, На службе России. Очерки по истории НТС, Frankfurt am Main 1986, http:// ntsrs.ru/content/p-stolypin-na-sluzhbe-rossii (dostęp: 30.05.2014).
} 
Narodowo-Pracowniczego Związku Nowego Pokolenia ${ }^{2}$, syn Piotra Stołypina, sławnego rosyjskiego polityka, autora reform mających przekształcić Rosję w liberalne imperium. Za co tak naprawdę dziękował po tylu latach Stołypin? Ten fragment jego wypowiedzi stał się dla mnie inspiracją do badań nad dziejami współpracy władz polskich z kołami emigracji rosyjskiej w latach 1926-1935, w kontekście pracy prometejskiej prowadzonej wobec innych narodów byłego imperium. Niniejszy artykuł stanowi skrótową prezentację problematyki i pierwszych efektów tych badań.

\section{Początki współpracy}

Pierwsze kroki $\mathrm{w}$ kierunku porozumienia $\mathrm{z}$ Rosjanami poczynił na polecenie Józefa Piłsudskiego Karol Wędziagolski wysłany do Paryża w celu nawiązania kontaktu z Borysem Sawinkowem i Nikołajem Czajkowskim³ . Wybór padł na Wędziagolskiego, ponieważ cieszył się zaufaniem zarówno Naczelnika, jak i Sawinkowa ${ }^{4}$. Przebieg negocjacji polsko-rosyjskich oraz pojawienie się idei „trzeciej Rosji” w sposób wyczerpujący opisał w swej monografii Polska i trzy Rosje Andrzej Nowak. Przypomnę jedynie, że jednym z jego wniosków było stwierdzenie, iż porozumienie $\mathrm{z}$ "trzecią Rosją” mogło doprowadzić do zajęcia Moskwy przez Sawinkowa tylko w bardzo sprzyjających warunkach, m.in. po opanowaniu i utrzymaniu Kijowa przez Ukraińców, do czego jednak nie doszło ${ }^{5}$. Sawinkow, opierając swoją akcję polityczną i militarną na Polsce, musiał zaakceptować prawo do samostanowienia narodów ${ }^{6}$. Nie jesteśmy w stanie stwierdzić, czy rzeczywiście miał zamiar przestrzegać tego prawa. Można mieć również poważne wątpliwości, czy byłby w stanie wymóc na społeczeństwie rosyjskim jego respektowanie ${ }^{7}$.

21927 - Nacionalnyj Sojuz Russkoj Mołodieżi; 1931 - Nacionalnyj Sojuz Nowogo Pokolenija; 1937 - Nacjonalno-Trudowoj Sojuz Nowogo Pokolenija, dalej: NTS.

${ }^{3}$ List Karola Wędziagolskiego do Piotra Wandycza, Sao Paulo, 28.12.1964, w: Rosyjski łącznik Naczelnika - wybór listów Karola Wędziagolskiego do Piotra Wandycza, oprac. A. Nowak, „Arcana” 70/71 (2006), s. 90-91.

4 A. Nowak, Polska i trzy Rosje. Studium polityki wschodniej Józefa Piłsudskiego (od kwietnia 1920 roku), Kraków 2001, s. 466 (wyd. uzup. 2014).

5 Ibidem, s. 606-607.

${ }^{6}$ Zasady podziału terytorialnego - najbardziej drażliwa kwestia, zarówno dla Polaków, jak i Rosjan - zostały wyłożone już w pierwszym numerze organu RKP, Россия и Польша, „Свобода” z 17 lipca 1920 r. W tym samym tonie pisał w osobnym artykule Sawinkow: „Отделившиеся ныне от России народы, образовавшия новыя государства имеют неоспоримое право на самостоятельное политическое бытие. Не силою орыжия, а лишь по добровольному соглашению может произойти соединение этих народов и будущей Россией через Учредительныя Собрания свои и Учредительное Собрание Русское. [...] Только тем же принципом самоопределения народов может быть разрешен «спор славян между собою»споры России и Польши”, Б. Савинков, Чего мы хотим, Свобода” 1 (17.07.1920).

7 Według Georgija Kutiepowa „On od Rosjan bynajmniej nie wymaga uznania Ukrainy”, zob. Depesza G. Kutiepowa do księcia Lwowa w Paryżu o rozmowie Sawinkowa z J. Piłsudskim, Warszawa, 16.06.1920, w: Sąsiedzi wobec wojny 1920 roku, oprac. J. Cisek, Londyn 1990, s. 106. 
Porozumienie z Piłsudskim wymagało też nawiązania współpracy z sojusznikami Polski: przedstawicielem Ukraińskiej Republiki Ludowej (URL), atamanem Symonem Petlurą ${ }^{8}$ oraz z generałem Stanisławem Bułak-Bałachowiczem, umyślnie lawirującym w tym czasie między tożsamością białoruską a rosyjskąa . Sawinkow był jedynym emigracyjnym przywódcą rosyjskim, który był gotów podjąć współpracę ze wszystkimi siłami antybolszewickimi w celu wyzwolenia Rosji. Owa chęć współpracy i wytyczenie nowych granic za pomocą plebiscytów ludnościowych czyniły z Sawinkowa, w optyce rosyjskiej opinii publicznej, osobę kontrowersyjną. Warto jednak przypomnieć, że jego współpracownicy, znani petersburscy intelektualiści, tworzący tzw. literacki triumwirat: Dimitrij Mereżkowski, Zinaida Gippius i Dimitrij Fiłosofow, w swoich poglądach byli jeszcze bardziej radykalni - według nich Polska powinna powrócić do granic przedrozbiorowych z 1772 r. $^{10}$

Działania Sawinkowa nie cieszyły się poparciem ani ogółu społeczeństwa rosyjskiego, ani zachodnich polityków, którzy woleli wspierać „białych”: Aleksandra Kołczaka, Antona Denikina i Nikołaja Judenicza. Akcja mogła nabrać tempa dopiero po klęsce Denikina i likwidacji jego armii, wczesną wiosną 1920 r., na Krymie. W połowie czerwca Piłsudski wydał zgodę na formowanie jednostek rosyjskich pod politycznym zwierzchnictwem Borysa Sawinkowa ${ }^{11}$. Pod koniec czerwca, pod przewodnictwem Fiłosofowa, odbyło się pierwsze posiedzenie Rosyjskiego Komitetu Politycznego (RKP) ${ }^{12}$, a 17 lipca wyszedł pierwszy numer jego politycznego organu - „Swoboda”, pod oficjalną redakcją sekretarza Mereżkowskich Władimira Złobina.

${ }^{8}$ Projekt umowy zawartej między URL a RKP w Polsce 18.11.1920, International Institute of Social History (dalej: IISH), Boris Viktoroviĉ Savinkov Papers (kolekcja online), dok. 138 i 139.

9 Zob. Umowa pomiędzy B. Sawinkowem a gen. Bułak-Bałachowiczem w sprawie zasad współdziałania, Warszawa, 27.07.1920, w: Sąsiedzi wobec wojny..., s. 111-112.

10 „Nie umawiając się, jednakowo odnieśliśmy się do Polski, do Polaków, znaleźliśmy się na tych samych, aż po szczegóły, pozycjach. Spór o «granice», ów czczy, karygodny i z gruntu absurdalny spór jednakowo nas oburzał. Kiedy Dima [Fiłosofow] po raz pierwszy wydrukował u Gzowskiego, że osławione granice z 72. roku to tylko sprawiedliwość - było tak, jakbyśmy podpisali się pod tym wszyscy", Z. Gippius, Dzienniki petersburskie. Dziennik warszawski, tłum. i oprac. H. Chłystowski, Warszawa 2010, s. 446.

11 A. Nowak, Jak rozbić rosyjskie imperium. Idee polskiej polityki wschodniej (1733-1921), Warszawa 1991, s. 263-265. Dowódcą formowanej w Polsce 3. Armii, wojskowo podporządkowanej zwierzchnictwu gen. Piotra Wrangla, został ostatecznie gen. Borys Piermykin. Pierwszy punkt umowy podpisanej przez B. Sawinkowa, D. Fiłosofowa i gen. por. P. Głazenapa brzmiał: „Wydzielony Oddział Rosyjski sformowany na terytorium Rzeczypospolitej Polskiej działa w ścisłej więzi moralnej z generałem Wranglem. Jednakże tymczasowo działa on całkowicie autonomicznie", Zasady współdziałania pomiędzy Rosyjskim Komitetem Politycznym a dowództwem oddziałów rosyjskich formowanych w Polsce, Warszawa, 7.07.1920, w: Sasiedzi wobec wojny..., s. 107.

12 Skład komitetu: prezes Sawinkow, wiceprezes Dimitrij Fiłosofow, Dimitrij Mereżkowski, Zinaida Gippius, Aleksandr Dickhoff-Derenthal, Nikołaj Bułanow, Borys Hoerszelman, Dimitrij Odiniec, Fiodor Rodiczew, Wiktor Sawinkow - brat Borysa, W. Ulianickij, Wiktor Portugałow; Z. Gippius, op. cit., s. 439; R.B. Spence, Renegade on the Left, New York 1991, s. 269; В.К. Виноградов, В.Н. Сафонов, Борис Савинков противник большевиков, w: Борис Савинков на Лубянке. Документыь, ред. А.Л. Литвин, Москва 2001, s. 7. 
12 października 1920 r., wbrew opinii polskiego MSZ oraz planom Piłsudskiego i kół wojskowych, chcących dać jeszcze nieco czasu sojusznikom na przygotowanie ofensywy, został podpisany przedwczesny, niekorzystny dla strony polskiej rozejm $\mathrm{z}$ bolszewikami ${ }^{13}$. Stawką, o jaką prawdopodobnie grał Piłsudski, były już jedynie ziemie wschodniej Białorusi oraz w mniejszym stopniu Kijów, lecz jego zdobycie i utrzymanie zależało już wtedy tylko od Ukraińców, a ich siły były niewystarczające $^{14}$. Dla Rosjan była to wstrząsająca wiadomość ${ }^{15}$. Poza samodzielnymi oddziałami Bałachowicza, Jakowlewa i Salnikowa, nawiasem mówiąc niebędącymi jednolitymi narodowościowo jednostkami rosyjskimi, 3. Armia nie wzięła udziału w walkach, gdyż nie była jeszcze dostatecznie zorganizowana i wyekwipowana. Rozejm oznaczał, iż dalszą walkę połączone siły rosyjsko-kozacko-białorusko-ukraińskie będą musiały stoczyć bez wsparcia Wojska Polskiego, co minimalizowało szansę na osiągnięcie sukcesu. Samotna ofensywa Bałachowicza i Sawinkowa na Białoruś oraz Piermykina i Petlury w kierunku Krymu uległa szybkiemu załamaniu - do początku grudnia powróciły wszystkie oddziały, którym udało się przekroczyć polską granicę, skąd zostały one skierowane do obozów internowania ${ }^{16}$. Wydarzenia te miały miejsce nieco później niż ewakuacja wojsk gen. Wrangla z Krymu na Bałkany. Tym samym ostatnia poważna próba wzniecenia kontrrewolucji uległa załamaniu.

Notowania RKP zaczęły gwałtownie spadać, co przejawiało się chociażby w zmianie nazwy na Rosyjski Komitet Ewakuacyjny (RKE). Sawinkow, szukając wyjścia z sytuacji, był zmuszony iść na coraz większe ustępstwa wobec innych narodów. Świadczy o tym projekt utworzenia Związku Państw na terenie byłego Imperium Rosyjskiego, uznanie de iure Estonii, Łotwy, Gruzji (co ciekawe, projekt

13 J. Borzęcki, Pokój ryski 1921 roku i kształtowanie się międzywojennej Europy Wschodniej, Warszawa 2012, s. 212-221. Autor w wyczerpujący sposób omawia warunki oraz okoliczności, w jakich podpisano rozejm.

14 Zgadzam się z opinią Andrzeja Nowaka i Joanny Gierowskiej-Kałłaur, że w koncepcji Piłsudskiego wspólna akcja Bałachowiwcza i Sawinkowa miała na celu przede wszystkim odbicie z rąk bolszewickich ziem wschodniej Białorusi, z czego nie do końca zdawał sobie sprawę sam Sawinkow; A. Nowak, Polska i trzy Rosje..., s. 606-607; J. Gierowska-Kałłaur, Straż Kresowa wobec kwestii białoruskiej. Deklaracje i praktyka, „Studia z Dziejów Rosji i Europy Środkowo-Wschodniej” 44 (2009), s. 32. Ze strony polskiej, w październiku 1920 r., żadna szersza akcja, jak np. podnoszona w publicystyce idea pochodu na Moskwę, nie mogła być brana pod uwagę. Piłsudski, jak również Sawinkow, a nawet Wrangel, głównie na skutek polityki Lloyda George’a (Francja bowiem, zmuszona do szukania zbliżenia z Londynem, nie mogła prowadzić w pełni samodzielnej polityki wschodniej), utracił szansę na wsparcie militarne Zachodu, który dążył do porozumienia z nową, bolszewicką władzą; A. Nowak, Pierwsza zdrada Zachodu. 1920 - zapomniany appeasement, Kraków 2015, s. 467-468.

15 Bliscy współpracownicy Sawinkowa, Gippius i Mereżkowski, jeszcze niedawno opiewający Naczelnika w broszurze Józef Piłsudski jako „zbawcę ludzkości”, z poczuciem zdrady wyjechali w październiku 1920 r. do Francji, co stało się jedną z przyczyn ich konfliktu z Fiłosofowem, który postanowił kontynuować działalność we współpracy z Polską, Z. Gippius, op. cit., s. 465.

16 Z. Karpus, Wschodni sojusznicy Polski w wojnie 1920 roku. Oddzialy wojskowe ukraińskie, rosyjskie, kozackie i białoruskie w Polce w latach 1919-1920, Torun 1999, s. 175. 
nie wspomina o Litwie, której los, ze względu na funkcjonowanie Litwy Środkowej, nie był jeszcze rozstrzygnięty ${ }^{17}$ oraz porozumienie $\mathrm{z}$ URL, w myśl którego uznano jej niepodległość i rząd na czele z Petlurą. Projekt ten został podpisany 17 marca 1921 r. przez przedstawicieli obu stron, w przededniu zawarcia polsko-sowieckiego traktatu pokojowego w Rydze; podtrzymywał on ustalenia konwencji zawartej między RKP a URL z 18 listopada 1920 r. ${ }^{18}$ Ponadto na początku stycznia odbyło się tajne zebranie RKE, na którym zdecydowano o reaktywowaniu Ludowego Związku Obrony Ojczyzny i Wolności, utworzeniu przy nim biura informacyjnego oraz zwołaniu na lipiec 1921 r. zjazdu organizacji antybolszewickich, na który zaproszono, co ważne, również nierosyjskie narody imperium ${ }^{19}$.

Otwarcie nowego rozdziału współpracy polsko-rosyjskiej utrudniały zapisy traktatu ryskiego, w którym obie strony zobowiązały się do nieudzielania schronienia i niewspierania ruchów politycznych godzących w niepodległość lub ustrój którejś ze stron ${ }^{20}$.

Wbrew punktom traktatu ryskiego przedstawiciele ruchów antybolszewickich nie opuścili Polski. Przeciwnie, w dniach 13-16 lipca 1921 r. w Warszawie, w siedzibie RKE przy ulicy Marszałkowskiej 68, odbył się zjazd organizacji antybolszewickich. Według rosyjskich badaczy stawiło się na niego 140 działaczy, w tym aż pięćdziesięciu z Rosji bolszewickiej ${ }^{21}$. Byli wśród nich również przedstawiciele organizacji ukraińskich, szef Ukraińskiej Misji Wojskowej gen. Wiktor Zieliński, organizacji białoruskich, kozackich, prawdopodobnie gruzińskich i innych. Na zjazd przybyli również Polacy, w tym wysłannik marszałka Piłsudskiego płk Bolesław Wieniawa-Długoszowski, oficer do zleceń szefa Sztabu Generalnego Stanisław Dowoyno-Sołłohub ${ }^{22}$ oraz przedstawiciele ambasad: brytyjskiej (agent Secret Intelligence Service Sidney Reyly i ppłk Emilius Clayton, członek misji wojskowej), francuskiej, belgijskiej, włoskiej i amerykańskiej². Uczestnicy zjazdu podkreślili konieczność współpracy między narodami byłego imperium w celu utworzenia „trzeciej Rosji” - szanującej prawa innych narodów i państw historycznych. Podjęli również decyzję o współpracy jedynie z państwami Ententy, wykluczając takową z Niemcami, naturalnymi - zdaniem delegatów - wrogami Rosji24.

17 IISH, BVSP, Projekt porozumienia między rządem URL a RKP w sprawie „Związku Państw”, mającym powstać na terytorium byłego Imperium Rosyjskiego, 23.02.1921, dok. 137-138.

18 IISH, BVSP, Protokół ze wspólnego zebrania przedstawicieli RKP i rządu URL na temat zawarcia porozumienia o współpracy, luty 1921, dok. 139.

19 R.B. Spence, op. cit., s. 269; В.К. Виноградов, В.Н. Сафонов, ор. cit., s. 10.

20 Artykuł V traktatu pokoju między Polską a Rosją i Ukrainą, z załącznikami, Ryga, 18.03.1921, Dokumenty z dziejów polskiej polityki zagranicznej 1918-1939, red. T. Jędruszczak, M. Nowak-Kiełbikowa, t. 1, Warszawa 1989, s. 155.

${ }^{21}$ В.К. Виноградов, В.Н. Сафонов, оp. cit., s. 11.

22 Ibidem, s. 11.

23 R.B. Spence, op. cit., s. 299.

24 Протокол решений съезда „Союза защиты и свободы Родины”, w: Борис Савинков на Лубянке.., s. 500-503. 
Działalność antybolszewickich organizacji była możliwa dzięki przyzwoleniu marszałka Piłsudskiego, liczącego się z możliwością wznowienia wojny na wiosnę 1921 r. oraz wykorzystania wspomnianych $\operatorname{sił}^{25}$, co jednak kolidowało z polityką rządu Rzeczypospolitej, który chciał dotrzymać zobowiązań traktatowych i naciskał na likwidację zbrojnych oddziałów białogwardyjskich działających przy granicy z Rosją bolszewicką oraz wydalenie ich przywódców ${ }^{26}$.

Wspomniany zjazd wywołał żywą reakcję bolszewików, którzy tym energiczniej zaczęli domagać się wydalenia „białogwardzistów”. Naciski rządu polskiego spowodowały, że z końcem października Sawinkow wraz z częścią swoich współpracowników musiał przenieść się do Pragi (wyjeżdżając, nie krył swojego żalu do Polaków $)^{27}$. Przymusowy wyjazd nie ominął również Dimitrija Fiłosofowa, który jednak rychło wrócił do Polski (w latach 1921-1924 pełnił funkcję kierownika polskiego oddziału Ludowego Związku Obrony Ojczyzny i Wolności). W następnych latach starano się wydalać jedynie osoby wrogo nastawione do Polski, dając jednocześnie formalną satysfakcję Związkowi Sowieckiemu, który nalegał, po zabójstwie połpreda Piotra Wojkowa oraz zamachu na Aleksieja Lizariewa, by państwo polskie usunęło ze swych granic działaczy antykomunistycznych ${ }^{28}$.

Mimo wydalenia głównych przywódców organizacji antybolszewickich, zdominowany przez piłsudczyków Oddział II Sztabu Generalnego nie zerwał kontaktów z Rosjanami. Szczególnym orędownikiem współpracy z organizacją Sawinkowa był szef Oddziału II ppłk Ignacy Matuszewski, który już w listopadzie 1920 r. napisał: „Posiadanie wpływu na grupę energiczną uczciwą rosyjską daje nam możność równie bolesnej interwencji w sprawy wewnętrzne przeciwnika. Tylko zachowanie tego atutu w swych rękach pozwoli na zmuszenie przeciwnika bez wypowiadania

25 T. Snyder, Tajna wojna. Henryk Józewski i polsko-sowiecka rozgrywka o Ukrainę, Kraków 2008, s. 38-39; w pierwszej połowie 1921 r. rozważano również użycie w podobny sposób sił, którymi dysponował Sawinkow; Raport szefa defensywy Oddziału II Sztabu Generalnego mjr. Terleckiego dla Naczelnego Dowództwa Wojska Polskiego, zawierający plan akcji zbrojnej oddziałów B. Sawinkowa i S. Pelury na terytorium USRR, 8.05.1921, w: Dokumenty i materiały do historii stosunków polsko radzieckich (dalej: DiM), t. 4, red. T. Cieślak, I.A. Chrienow, Warszawa 1965, s. $17-19$.

${ }^{26}$ Pismo Ministerstwa Spraw Zagranicznych do Poselstwa RP w Paryżu w sprawie wydalenia sawinkowców z Polski, Warszawa, 8.10.1921, w: DiM, t. 4, s. 87-92.

27 R.B. Spence, op. cit., s. 316.

${ }^{28}$ Interesujące, że wśród Rosjan zamieszanych w zamach na Piotra Wojkowa znalazł się również późniejszy uczestnik ruchu oporu, zamordowany w czasie wojny przez gestapo w Warszawie A. Pawlukiewicz oraz agent Oddziału II Michaił Jakowlew, który zorganizował m.in. broń dla Borysa Kowerdy; Relacja Borysa Kowerdy, http://zhurnal.lib.ru/g/gorbunow_g_a/koverda.shtml (dostęp: 5.05.2015); A.S. Kowalczyk, Warschau: Die russiche Emigration in Polen, w: Der grosse Exodus. Die russische Emigration und ihre Zentren 1917 bis 1941, hrsg. K. Schlögel, München 1994, s. 210-211. Żaden z wymienionych nie poniósł konsekwencji, w przeciwieństwie do niezwiązanych ze sprawą, lecz sprawiających problemy państwu polskiemu atamana Derkacza (W. Adamowicz) i redaktora „Utra” A. Romaszewa; М. Яковлев, К выселению русских эмигрантов из Польши, „Новая Россия”, 28.08.1927, nr 41, s. 3. 
mu wojny do przestrzegania artykułu II-ego preliminarzy. Drogą udatnie przeprowadzonej reorganizacji i wzmocnienia partii SR udaremni się najniebezpieczniejszy dziś moment zjednoczenia społeczeństwa rosyjskiego bez względu na jego poglądy socjalne pod kierownictwem partii komunistycznej, jako reprezentantki Rosji [podkr. - Ł.D.]"29. Matuszewski uważał również za szczególnie korzystną dla Polski destrukcyjną ideowo działalność Sawinkowa oraz deklarowanie przez niego „rezygnacji z wielkomocarstwowej Rosji”30.

Działalność Ludowego Związku została zakończona po wysłaniu przez Sawinkowa listu z Łubianki (na początku 1924 r., w wyniku prowokacji, udał się on do Związku Sowieckiego, gdzie został aresztowany) ${ }^{31}$, w którym nakłaniał on Fiłosofowa do uznania władzy bolszewickiej ${ }^{32}$. Fiłosofow zdał relację z całej sprawy marszałkowi w czasie osobistej wizyty w Sulejówku, zachowując jego zaufanie ${ }^{33}$. W 1923 r. Oddział II zakończył również współpracę z organizacją dywersyjno-wywiadowczą „Wilk”, utworzoną przez Borysa Sawinkowa, a kierowaną przez jego brata Wiktora. Powodem były konflikty między Oddziałem II a MSZ, niska ocena działalności Rosjan oraz liczne aresztowania - tylko w latach 1921-1922 WCzK aresztowała 500 wywiadowców ${ }^{34}$. W tym czasie Fiłosofow był już liderem i głównym orędownikiem współpracy emigracji rosyjskiej z państwem polskim ${ }^{35}$.

29 Z raportu przedstawiciela Sztabu Generalnego WP ppłk. I. Matuszewskiego o odprawie z polskimi attachés wojskowymi na Łotwie i w Estonii w sprawie wytycznych postępowania wobec Rosji Radzieckiej, Ryga, 19.11. 1920, w: DiM, t. 3, red. N. Gąsiorowska-Grabowska, I.A. Chrienow, Warszawa 1964, s. 527-528.

${ }^{30}$ Memoriał szefa Oddziału II Sztabu Generalnego WP I. Matuszewskiego w sprawie wykorzystania grup B. Sawinkowa i S. Pelury do akcji antyradzieckiej, Warszawa, kwiecień 1921, w: DiM, t. 4, s. 15-16; Raport Ekspozytury O II SG we Lwowie do Naczelnego Dowództwa WP zawierający zasady współpracy z agencją wywiadowczą W. Sawinkowa, Lwów, 19.07.1921, w: DiM, t. 4 , s. 27-30.

31 Według Michaiła Hellera Sawinkow, mniej lub bardziej świadomie, już od grudnia 1921 r. mógł być sowieckim agentem wpływu, który z pobudek patriotycznych podjął pewną grę z bolszewikami, nie mając świadomości, że tak naprawdę był tylko ich pionkiem. 10 grudnia $1921 \mathrm{r}$. w Londynie odbył rozmowę z Leonidem Krasinem, bliskim współpracownikiem Lenina, który zabiegając na Zachodzie o oficjalne uznanie władzy bolszewickiej i pożyczki dla niej, przedstawiał fałszywy obraz Rosji bolszewickiej jako państwa w gruncie rzeczy liberalnego. Tak wprowadzony w błąd Sawinkow przekazywał te informacje wielu ważnym politykom europejskim, w tym m.in. Piłsudskiemu; M. Heller, List Borysa Sawinkowa do marszałka Piłsudskiego, w: Sowietskij Sojuz. Wybór, red. J. Karpiński, I. Lasota, Wrocław 1989, s. 83-84.

32 J. Czapski, Świat w moich oczach, Ząbki-Paris 2001, s. 143.

33 D. Fiłosofow do B. Sawinkowa, Warszawa, 16.09.1924 r., w: Из переписки Д.В. Философова. 1920-1932, „Наше Наследие” 2002, nr 63-64, http://www.nasledie-rus.ru/podshivka/6407.php (dostęp: 14.01.2015); J. Czapski, Świat..., s. 144.

${ }^{34}$ K. Paduszek, Polski wywiad wojskowy na Rosje Sowiecka/Związek Sowiecki w latach 1921-1927, Warszawa 2014, s. 300-305, mps pracy doktorskiej w Bibliotece Instytutu Historycznego Uniwersytetu Warszawskiego.

35 Po stracie bliskich współpracowników swoje pozostanie argumentował: „przyszli historycy będą skłonni odczuwać naszą walkę z bolszewikami w kategoriach konfliktu pomiędzy Rosjanami i Polakami. Taka prosta dialektyka przedstawia fałszywie kręty i zawiły konflikt, który doprowadził 


\section{Powrót marszałka - prometeizm a kwestia rosyjska}

Przewrót majowy 1926 r. rozbudził wśród Rosjan nadzieję z jednej strony na poprawę losu ${ }^{36}$, a $z$ drugiej - szczególnie wśród działaczy organizacji emigracyjnych - na zaostrzenie stosunków ze Związkiem Sowieckim ${ }^{37}$. Tymczasem Piłsudski nie zamierzał obierać ostrego antysowieckiego kursu. Dążenie do zawarcia traktatów, w myśl polityki równowagi, zarówno ze Związkiem Sowieckim (1932 - traktat o nieagresji), jak i Rzeszą Niemiecką (1934 - deklaracja o niestosowaniu przemocy), nie pozostawiało zbyt wiele miejsca na działania ofensywne ${ }^{38}$. Próżno szukać po $1926 \mathrm{r}$. działań podobnych do tych $\mathrm{z}$ pierwszej połowy lat dwudziestych, kiedy nie tylko planowano, ale również realizowano akcje dywersyjne (zimowy pochód gen. Jurki Tiutiunnyka) ${ }^{39}$. Po 1926 r. wsparcie zarówno dla Rosjan, jak i narodów prometejskich ograniczało się do legalnych wystąpień oraz nosiło charakter defensywny ${ }^{40}$.

do mojego postanowienia, aby pozostać w Polsce i walczyć obok Borysa Sawinkowa i Polaków”, J.S. Durrant, Borys Sawinkow w Warszawie - z pamiętników D.W. Fiłosofowa (artykuł oraz pamiętnik Moj Put', znajduje się w zbiorach Durranta), kopię mps. udostępnił autorowi prof. Andrzej Nowak. W liście z Jugosławii z 1921 r. pisał: „Mój pobyt w Polsce - to były moje lata najlepsze, robiłem to, co chciałem, a nie to, co mi się chciało", J. Czapski, Wyrwane strony, Warszawa 2010, s. 75. Karol Wędziagolski pisał o nim: „przesiąkł na wskroś romantyką nowej ery w stosunkach polsko-rosyjskich", K. Wędziagolski, Pamiętniki, wojna i rewolucja, kontrrewolucja, bolszewicki przewrót, warszawski epilog, Warszawa 2007, s. 429.

36 „Виленское Утро”, 1660 (16.05.1926); ibidem, 1662 (18.05.1926); „За Свободу!” 121 (27.05.1926); М. Арцыбашев, Обезьяна о человеке, „За Свободу!” 128 (6.06.1926).

37 Kierownictwo ROWS, wciąż dezinformowane przez MOCR, liczyło na rychły wybuch powstania antybolszewickiego; w latach 1927 i 1928 doszło do zamachów na połpreda Piotra Wojkowa oraz przedstawiciela handlowego Aleksandra Lizariewa, wzmógł się przerzut rosyjskiej bibuły do ZSRS, swoje działania zintensyfikowały również tajne organizacje na Kresach Wschodnich, dzielono nawet przyszłe stanowiska: „Wniosek ten [na zebraniu Wileńskiego Towarzystwa Rosyjskiego] postawił Gawryłow, który oświadczył, że ludność rosyjska musi być odpowiednio przygotowana do przewrotu, jaki ma nastąpić w Rosji po upływie pół roku, przyczem zaznaczył, że po upadku władzy Sowietów Wilno będzie należało do Rosji, a Zarząd WTR stanie się pierwszym prowizorycznym zarządem Wileńszczyzny i innych ziem, które obecnie należą do Polski, a zostaną oddane Rosji. [...] z chwilą objęcia władzy przez Rosję monarchistyczna, Russkoje Narodnoje Obiedinienie nie będzie odgrywało żadnej roli, ponieważ członkowie tej organizacji rekrutują się przeważnie z obywateli polskich", Archiwum Akt Nowych w Warszawie (dalej: AAN), Ministerstwo Spraw Wewnętrznych (dalej: MSW), sygn. IV/78, Sprawozdanie z życia mniejszości narodowych za styczeń, luty i marzec 1929 r., Warszawa 1929, s. 21. W zachodnioeuropejskiej prasie emigracyjnej krążyły pogłoski o szykowanej na lato 1930 r. ofensywie sprzymierzonych mającej wyzwolić Rosję od bolszewików; P. Kropp, Sekrety wywiadu francuskiego, Warszawa 1999, s. 381-382. Zaginięcie (likwidacja przez OGPU) gen. Aleksandra Kutiepowa podkopało nadzieje Rosjan.

${ }^{38}$ M. Kornat, Idea prometejska a polska polityka zagraniczna (1921-1939/1940), w: Ruch prometejski $i$ walka o przebudowę Europy Wschodniej (1918-1940), red. M. Kornat, Warszawa 2012, s. 55-59.

39 T. Snyder, op. cit., s. $38-39$.

${ }^{40}$ P. Libera, Ewolucja ruchu prometejskiego w okresie międzywojennym, w: Ruch prometejski..., s. 226-227. 
Według Pawła Libery po podpisaniu paktu o nieagresji z ZSRS w 1932 r. ruch prometejski znalazł się wręcz w kryzysie, który trwał do jego reformy w $1935 \mathrm{r}^{41}$

Po likwidacji organizacji Sawinkowa w pierwszej połowie lat dwudziestych, poza jego bliskim współpracownikiem Fiłosofowem oraz garstką jego zwolenników nie było ośrodka rosyjskiego o profilu antyimperialnym, opowiadającego się chociażby za ograniczoną współpracą z narodami prometejskimi oraz akceptującego polską granicę wschodnią ${ }^{42}$.

Co więcej, na przełomie 1926 i 1927 r. została wykryta afera inspiracyjna sowieckiego wywiadu o kryptonimie „Trust”. Według jednej z wersji, forsowanej przez trzech oficerów Oddziału II, wykrycie mistyfikacji miało się odbyć po osobistej interwencji Piłsudskiego, który zainteresował się sprawą już w lipcu 1926 r. Polecił on organizacji „Trust”, poprzez mjr. Janusza Ilińskiego, zastępcę polskiego attaché wojskowego w Paryżu, zdobycie sowieckich planów osłony i koncentracji, po otrzymaniu których ostatecznie rozkazał zerwać współpracę ${ }^{43}$. Z uwagi na

41 Ibidem, s. 227-229.

42 Granica ryska była nie do zaakceptowania nie tylko dla emigracyjnego centrum czy prawicy, ale również dla czołowych działaczy lewicowych bądź liberalnych, takich jak Aleksandr Kiereński, Władimir Burcew, Paweł Milukow czy nawet Mark Wiszniak; M. Kornat, Idea prometejska..., s. 44; M. Wiszniak, Years of Emigration 1919-1969, Paris-New York 1970, s. 67.

43 W. Michniewicz, Wielki Bluff sowiecki, Chicago 1991, s. 245-250; W.T. Drymmer, Trust, „Kultura” 11/217 (1965), s. 102; r. Wraga, Trust, „Kultura” 4/21-22 (1949), s. 175; również Siergiej Wojciechowskij, podając tę informację za Wragą, nie wykluczał udziału Piłsudskiego; С.Л. Войцеховский, Трест. Воспоминания и документы, Канада 1974, s. 98; szerzej na temat okoliczności zakończenia współpracy z Rosjanami: A. Krzak, Czerwoni azefowie: afera „MOCR-Trust" 1922-1927, Warszawa 2010, s. 124-126. Zadania badaczy na temat roli Piłsudskiego w wykryciu operacji inspiracyjnej są podzielone (literatura dotycząca operacji Trust liczy już kilkaset pozycji - analiz, monografii i artykułów - ze względu na niemożność odwołania się do nich wszystkich, skupimy się jedynie na najnowszych pracach polskich historyków). Zarówno Konrad Paduszek, jak i Marek Świerczek twierdzą, iż wspomnienia „dwójkarzy” miały służyć mitologizacji osoby marszałka, natomiast Andrzej Pepłoński i Wojciech Włodarkiewicz podążają za wersją przedstawioną przez byłych oficerów „dwójki” podkreślając osobisty udział marszałka w wykryciu sowieckiej operacji; K. Paduszek, op. cit., s. 332; M. Świerczek, Udział Wiktora Tomira Drymmera $w$ aferze MOCR-Trust $w$ świetle jego artykułu $z 1965$ r. pod tytułem Trust. Wstęp do analizy, „Przegląd Bezpieczeństwa Wewnętrznego” 10 (2014), s. 165-166; A. Pepłoński, Wywiad polski na ZSRR 1921-1939, Warszawa 1996, s. 284-285; W. Włodarkiewicz, Przed 17 września 1939 roku. Radzieckie zagrożenie Rzeczypospolitej w ocenach polskich naczelnych władz wojskowych 1921-1939, Warszawa 2002, s. 63. Moim zdaniem ewentualne polecenie zaprzestania współpracy w grudniu 1926 r. nie mogło zostać wykonane natychmiastowo - zakończenie tak skomplikowanej operacji wymagało czasu. W kwietniu 1927 r. Sowieci zdecydowali się ujawnić operację (w celach dalszej dezinformacji), zapewne zorientowawszy się, że polski wywiad przestał ufać „Trustowi”, r. Wraga, O szpiegach prowokatorach i naiwnych emigrantach, „Wiadomości” 1961, nr 806. Za tezą tą przemawia fakt, iż już 27 maja 1927 r. w Ekspozyturze nr 2 pojawiła się propozycja analogicznej operacji wymierzonej w ZSRS. Zatem niemożliwe jest, by Oddział II zaczął wycofywać się ze współpracy z „Trustem” dopiero w kwietniu 1927 r.; zob. treść propozycji: W. Stanisławski, Myśl polityczna emigracji rosyjskiej w II Rzeczpospolitej: interpretacje przeszłości $i$ koncepcje polityczne, mps rozprawy doktorskiej w Bibliotece Instytutu Historycznego 
niezwykłą kompromitację Oddziału II, inspirowanego od 1921 r. przez Sowietów, jego ówczesny szef ppłk Tadeusz Schaetzel odpowiadał za zakończenie współpracy z „Trustem”. Według jednej z tez, miał on poróżnić się z Marszałkiem w sprawie „Trustu”; przypuszcza się, że to mogło być powodem jego odejścia z funkcji szefa Oddziału II i przeniesienia w lutym 1929 r. do służby w MSZ ${ }^{44}$.

Mimo znacznej różnicy poglądów na kształt przyszłej Rosji między emigracją rosyjską a narodami prometejskimi oraz kompromitacji tej pierwszej w wyniku afery „Trust”, władze polskie utrzymały oba kierunki współpracy. Nabrano jednak do Rosjan większej nieufności i zaczęto szukać innych źródeł informacji wywiadowczej, przenosząc ciężar współpracy na narody „prometejskie” oraz biały wywiad prowadzony przez attachés wojskowych (nie zaryzykowano już współpracy z żadną organizacją działającą w ZSRS).

Stosunek ruchu prometejskiego do emigracji rosyjskiej w polityce państwa polskiego można by porównać do aorty i cienkiej żyły, której przecięcie mogłoby jednakże poskutkować wykrwawieniem się całego organizmu. Rozumiem przez to konieczność współpracy - nawet jeśli miałaby ona przynosić nikłe efekty, to pozwalała zachować pewną kontrolę nad oboma strumieniami, osłabiając nurt proniemiecki oraz prosowiecki. Oba z każdym rokiem zyskiwały coraz większe wpływy zarówno wśród narodów prometejskich, jak i emigrantów rosyjskich, czego dobitnym przykładem był ruch rosyjskich faszystów, rozwijający się w Niemczech i na Dalekim Wschodzie, oraz mładorosów Aleksandra Kazem-Beka ${ }^{45}$.

Ową żyłą była przede wszystkim grupa Fiłosofowa, który przyciągnął do siebie również sympatyków ruchu nowopokoleńców, do wybuchu wojny światowej działających głównie przy wsparciu ze strony władz Jugosławii oraz w porozumieniu ze służbami Polski i Japonii ${ }^{46}$ (w Polsce funkcjonowały również inne antykomunistyczne grupy rosyjskie, których działalność, mimo ich antypolskiego nastawienia, tolerowano do początku lat trzydziestych). Fiłosofow posiadał wyjątkową pozycję w środowisku rosyjskim ze względu na jego znajomość z Naczelnikiem. W latach 1920-1926, jak wspomina, odbył z nim około piętnastu rozmów, na audiencjach w Belwederze i spotkaniach w Sulejówku ${ }^{47}$; spośród emigrantów rosyjskich był jednym z nielicznych, a może nawet jedynym, któremu

Uniwersytetu Warszawskiego, s. 263, przyp. 173. Niestety, z braku dostępu do pełnej dokumentacji, a nawet pracy, która zbierałaby cały dostępny materiał źródłowy i obszerną literaturę przedmiotu, nie da się odpowiedzieć jednoznacznie na pytanie, jaka była rola Piłsudskiego w wykryciu operacji „Trust”, choć ze względu na wagę, jaką przykładał on do tego typu działań, nie można wykluczyć, że była istotna. Wydaje się jednak, że wykrycie operacji miało miejsce przed kwietniem $1927 \mathrm{r}$.

${ }^{44}$ M. Kornat, Tadeusz Schaetzel (1891-1971) nota biograficzna, „Pressje” 2010, nr 22-23, s. 98.

45 AAN, MSW, sygn. IV/95, Sprawozdanie z życia mniejszości narodowych za II kwartał 1934 r., Warszawa 1934, s. 46.

46 В.М. Байдалаков, Да возвлечится Россия. Да гибнут наши имена... Воспоминания председатела НТС 1930-1960 г2., Москва 2002, s. 15.

47 P. Mitzner, Warszawski krąg Dymitra Fiłosofowa, Warszawa 2015, s. 179. 
marszałek ufał ${ }^{48}$. Po śmierci Piłsudskiego, w odpowiedzi na list z kondolencjami od Fiłosofowa, Tadeusz Schaetzel odpisał: „Z osób niepolskiej narodowości jest Pan w pierwszym szeregu tych, którzy stoją nad Jego trumną, mogą się czuć jemu bliscy"49. Piłsudski w oczach emigrantów powszechnie uważany był za rusofoba ${ }^{50}$, natomiast Fiłosofow, przełamujący proste schematy, dostrzegał w nim sojusznika: „Rzecz dziwna [...], że polscy moskalofobi lubią w Rosji to, co my lubimy i nienawidzą w niej tego, czego i my nienawidzimy"51. Wśród wielu Polaków, których poznał w 1920 r., byli również Tadeusz Schaetzel, Walery Sławek, Bogusław Miedziński, Roman Knoll, Karol Wędziagolski, Stanisław Stempowski, możliwe, że także Tomasz Arciszewski oraz, jak twierdzi Wojciech Stanisławski, poprzez Szymona Askenazego, Józef Beck, Bolesław Wieniawa-Długoszowski ${ }^{52}$ oraz, być może, Tadeusz Hołówko, z którym miał okazję spotykać się w następnych latach ${ }^{53}$. Jak widać, w kręgu znajomości Fiłosofowa znaleźli się czołowi polscy działacze prometejscy (Schaetzel, Knoll, Stempowski, Hołówko), jak również ukraińscy oraz gruzińscy, z którymi utrzymywał sporadyczne kontakty, chociażby z okazji 19. rocznicy powołania armii URL w maju 1927 r. czy też balu ukraińskich studentów w lutym 1926 r. ${ }^{54}$

\section{Wojskowe oraz cywilne instytucje państwowe we współpracy z Rosjanami}

Zasadniczy ciężar współpracy z Rosjanami spoczywał na Oddziale II Sztabu Generalnego, w tym na oficerach Referatu „Wschód”, o czym w dalszej części. Rosjanie byli również pod obserwacją pracowników Referatu „Narodowościowego”

48 Przekazał Piłsudskiemu paczkę z listami od aresztowanego Sawinkowa; podobno marszałek nie uwierzył w jego zdradę, a cała sprawa nie nadwyrężyła jego zaufania do Fiłosofowa; J. Czapski, Świat..., s. 143; o zaufaniu, jakim darzył go marszałek, miał wspominać również B. Miedziński, patrz: J.S. Durrant, Zapomniany Warszawianin, mps w archiwum „Kultury” w Maisons-Laffitte, k. 11.

${ }^{49}$ Cyt. za: W. Stanisławski, „Rycerz przegranej sprawy”? Kontakty Dymitra Fiłosofowa z polskimi elitami kulturalnymi, w: Emigracja rosyjska losy i idee, red. r. Bäcker, Z. Karpus, Łódź 2002, s. 317.

${ }^{50}$ Emigranci nie mogli wybaczyć Piłsudskiemu wyprawy kijowskiej z wiosny 1920 r., która miała na celu utworzenie niepodległej Ukrainy. Powszechnie uznano ten plan za zamach na Rosję, po cichu przyznając słuszność oficerom carskim, którzy, na wezwanie gen. Brusiłowa, z pobudek patriotycznych zaczęli masowo wstępować w szeregi Armii Czerwonej, by bronić idei świętej Rusi. Wtedy, jak zauważył Alain Besançon, nacjonalizm rosyjski połączył się z komunizmem; A. Besançon, Święta Ruś, tłum. Ł. Maślanka, Warszawa 2012, s. 109.

51 Cyt za W. Stanisławski, Warszawski Rosjanin, „Twórczość” 58 (1996), nr 4, s. 163; w podobnym tonie był utrzymany jego artykuł z 1931 r.; Д.В. Филосо́фов, Белведер, „За Свободу!” 13 (15.01.1931), s. 2.

52 W. Stanisławski, Myśl polityczna..., s. 327.

53 E. Wiszka, Emigracja ukraińska w Polsce 1920-1939, Toruń 2004, s. 209.

${ }^{54}$ Ibidem, s. 193-194, 209; z młodszego pokolenia prometeistów poznał Jerzego Giedroycia; J. Czapski, Świat..., s. 142. 
Ekspozytury nr 2 Oddziału II SG. Jej głównym zadaniem była praca prometejska wśród nierosyjskich narodów ZSRS ${ }^{55}$. Referat prowadził prace przygotowawczo-dywersyjne, $\mathrm{w}$ tym celu wspomagając różne organizacje założone przez wychodźców z ZSRS (poza rosyjskimi) ${ }^{56}$. Obserwacje oficerów pozostających na placówkach wskazywały na konieczność zachowania niezwykłej ostrożności wobec Rosjan, którzy mogli być przydatni jedynie w pracy kontrwywiadowczej ${ }^{57}$. Do owej współpracy starano się również zniechęcić wywiad japoński, o czym świadczy fragment zaszyfrowanej korespondencji z placówki Cholski ze stycznia 1935 r. "Wprawdzie wewnątrz «Kwiatu Wiśni» [wywiad japoński] gospodaruje pasożyt «Ćma biała» [biała emigracja], powinna być więc wywarta akcja metowców [oficerów Oddziału II pozostających na Dalekim Wschodzie] w kierunku zorientowania Wyspy o szkodliwości samego udziału Ćmy białej" ${ }^{8}$. Równie ważnym problemem, obok penetracji organizacji „białych” przez wywiad sowiecki, były ich poglądy na przyszłą Rosję, która miała pozostać niepodzielna, w ostateczności z autonomiami dla niektórych narodów. To wymagało stałego monitorowania działań emigrantów próbujących zwalczać prometeistów: „zarówno rosyjscy politycy emigracyjni, jak i sowieccy starają się sparaliżować akcję separatystów"59.

55 Archiwum Instytutu Pamięci Narodowej w Warszawie (dalej: AIPN) BU 1572/1017, Pracownicy ekspozytury nr 2 Oddziału II Sztabu Głównego. Komunikat Nr 5 Głównego Zarządu Informacji MON, k. 6.

56 AIPN BU 1572/1165, Oddział II Sztabu Głównego WP, Referat „Wschód” w latach 1929-1939 organizacja, pracownicy, akta. Współpraca z wywiadem angielskim. Opracowanie płk. Gajewskiego z Głównego Zarządu Informacji MON, wykazy placówek zagranicznych, k. 146.

57 AIPN BU 2602/1440, Zarząd II Sztabu Generalnego WP w Warszawie, Teczka I, Działalność Oddziału II Sztabu Głównego w latach 33-39, raporty, k. 272.

58 Ibidem, k. 352.

59 „Stosunek jej [emigracji] do problemu separatyzmu jest zasadniczo wrogi, przyczem pod tym względem w obozie emigracyjnym panuje zadziwiająca jednomyślność, bez względu na różnice przekonań politycznych, koncepcyj odbudowy przyszłego państwa rosyjskiego itd. Istnieją naturalnie pewne drobne różnice zdań w zależności od kierunku politycznego, zasadniczo jednak panuje pod tym względem, jak już powiedziałem, zupełna jednomyślność. Emigracja nie chce słyszeć o jakimś podziale przyszłej Rosji i choćby najmniejszem uszczupleniu jej terytoriów, głosząc ideę «Jedinoj i niedielimoj» Rosji [podkreślone na czerwono w oryginale]. W nastrojach emigracji dokonał się siłą rzeczy pewien przewrót. Godzi się już ona z faktem istnienia Niepodległości Polski”, Instytut im. Józefa Piłsudskiego w Nowym Jorku, Ukraińska Misja Wojskowa w Polsce, 701/7/5, Komunikaty informacyjne Oddziału II Sztabu Głównego i Ministerstwa Spraw Wewnętrznych. Stosunek Rządu Sowieckiego i emigracji Rosyjskiej do problemu narodowościowego w Rosji, Raport szefa Oddziału II SG ppłk. Tadeusza Pełczyńskiego z 28.07.1930 r., skan 717, s. 7 (kolekcja online). Kontroli podlegały również główne organy prasowe „białej” emigracji, ibidem, s. 208-215 (kolekcja online); ibidem, skan 714, s. 4 (kolekcja online). Bolszewicy inspirowali również prasę monarchistyczną, podsycając antypolskie nastroje: „W kwietniu b.r. ukazała się w dzienniku monarchistów rosyjskich wychodzącym w Belgradzie p.t. «Carskij Wiestnik» (Nr 89 z dnia 27 IV b.r.) sensacyjna wiadomość o rzekomej umowie zawartej między Rządem Polskim, a przedstawicielami kaukaskich, tatarskich, ukraińskich i kozackich organizacyj niepodległościowych, w sprawie przyszłego podziału terytorialnego Rosji. Już z samego poplątania nazwisk poszczególnych przedstawicieli wnosić można, że wiadomość ta była również 
Znaczna część akcji prometejskiej była prowadzona również przez cywilne instytucje, w tym pracowników ministerstw, mających za sobą często pracę w Oddziale II. Istnieją dowody, że niektórzy z nich byli zainteresowani również współpracą z wybranymi kołami rosyjskimi, takimi jak środowisko Fiłosofowa, nowopokoleńców, a nawet szerzej jewroazijców. Taką współpracę próbowano nawiązać z sympatyzującym z ruchem eurazjatyckim Siergiejem Wojciechowskim, autorem artykułu Polska a Eurazja, opublikowanego w drugim numerze „Drogi” z 1928 r., proponując mu na początku 1928 r. spotkanie z profesorami Marianem Zdziechowskim i Janem Kucharzewskim w Instytucie Wschodnim. Również sami Rosjanie przebywający w Polsce byli zainteresowani współpracą z władzami polskimi, o czym świadczy postać młodego działacza „Wileńskiej Grupy Eurazjatyckiej” Andrieja Surkowa, który dążył do reinterpretacji doktryny eurazjatyckiej, by była ona akceptowalna dla innych narodów Rosji ${ }^{60}$. Główną osobą odpowiedzialną zarówno za działalność prometejską, jak i kontakty z Rosjanami z ramienia MSZ, był kierownik Wydziału Wschodniego, którym od 1927 r. był Tadeusz Hołówko ${ }^{61}$, a po nim, od 1931 r., Tadeusz Schaetzel.

Na początku lat trzydziestych władze polskie przeprowadzały konsolidację emigracji i mniejszości rosyjskiej wokół obozu rządzącego. W 1931 r. minister spraw wewnętrznych Bronisław Pieracki zatwierdził statut propaństwowych organizacji: Związku Rosyjskich Organizacji Mniejszościowych (ZROM) ${ }^{62}$ oraz emigracyjnego

inspirowana zapewne przez bolszewików, tembardziej, że niezwłocznie została przytoczona przez pisma sowieckie”, ibidem, Raport szefa Oddziału II ppłk. Tadeusza Pełczyńskiego z 28.07.1930 r., skan 716, s. 4 (kolekcja online). Raporty MSZ i II Oddziału SG dotyczyły emigracji rosyjskiej w Niemczech, Francji, Finlandii, Węgrzech, Rumunii, Serbii, Austrii, Państwach bałtyckich i Mandżurii; W. Stanisławski, Myśl polityczna..., s. 258.

${ }^{60}$ W. Stanisławski, Myśl polityczna..., s. 202-203, przyp. 223 i 226; r. Backer, Międzywojenny eurazjatyzm. Od intelektualnej kontrakulturacji do totalitaryzmu?, Łódź 2000, s. 208-209. Na obecnym etapie zmuszony jestem pominąć temat współpracy Rosjan z polskimi ośrodkami sowietologicznymi oraz akademickimi, zaznaczając jednakże, że takowa istniała, zarówno w przypadku wspomnianego Instytutu Wschodniego, jak i Instytutu Naukowo-Badawczego Europy Wschodniej i Szkoły Nauk Politycznych w Wilnie, gdzie w roku akademickim 1931/1932 na studia uczęszczało więcej Rosjan (15) aniżeli przedstawicieli wszystkich innych mniejszości; M. Kornat, Instytut Naukowo-Badawczy Europy Wschodniej w Wilnie (1930-1939) i jego wkład w rozwój polskiej sowietologii, „Kwartalnik Historyczny” 107 (2000), nr 3, s. 50.

${ }^{61}$ W. Materski, Na widecie. II Rzeczpospolita wobec Sowietów 1918-1943, Łódź 2005, s. 329. Przed objęciem tej funkcji Hołówko utrzymywał łączność między marszałkiem a narodami byłego Imperium Rosyjskiego: „W ciągu kilkunastu miesięcy [w 1925 r.] odbył on całą serię poufnych podróży zagranicznych, których celem było odnowienie kontaktów pomiędzy Warszawą a rozproszonymi środowiskami emigracji antysowieckiej. Jego rozmówcami byli przedstawiciele organizacji kaukaskich i Rosjanie, zasadnicze znaczenie miały jednak negocjacje prowadzone z Ukraińcami”, J.J. Bruski, Między prometeizmem a Realpolitik. II Rzeczpospolita wobec Ukrainy sowieckiej1921-1926, Kraków 2010, s. 212.

6220 VII 1931 r., Warszawa, Pismo Ministra Spraw Wewnętrznych Bronisława Pierackiego do komisarza rządu m.st. Warszawy oraz wszystkich wojewodów z wyjątkiem śląskiego, pomorskiego, poznańskiego i kieleckiego, dotyczące Związku Rosyjskich Organizacji Mniejszościowych w Polsce, 
Rosyjskiego Komitetu Społecznego (RKS) ${ }^{63}$. W pracach nad utworzeniem RKS uczestniczył naczelnik Wydziału Wschodniego MSZ Tadeusz Hołówko. To on odbierał z rąk Fiłosofowa memorandum dotyczące powołania Rosyjskiego Komitetu Społecznego ${ }^{64}$. Z nim również, przed złożeniem pisma, odbywał poufne konsultacje Fiłosofow, na co wskazuje treść listu Siergieja Kielnicza, którego próbowano pozyskać dla współpracy: „Он [Fiłosofow] обещает етому Ком[ите]ту полную поддержку со стороны правительственных кругов, как материальную, так и политическую” "65. Kielnicz, jako korespondent „Siegodnia” mógł się okazać cennym współpracownikiem, tym bardziej że oprócz utworzenia Komitetu, Fiłosofow planował „odświeżyć” „Za Swobodu!” (wsparcia finansowego obiecywał udzielić Hołówko ${ }^{66}$. Według Kielnicza była to próba wyjścia z politycznej izolacji, w jakiej tkwił, krytykowany lub ignorowany przez większość emigrantów. Pośrednikiem w przekazywaniu oferty Fiłosofowa był korespondent gazet „Wozrożdenije” i „Siegodnia”, były rezydent ROWS Siergiej Wojciechowski. Kielnicz nie zgodził się na współpracę ani w 1928, ani w 1930 r. ${ }^{67}$; w obu przypadkach finansowanie zapewniał Hołówko ${ }^{68}$. Pozyskanie go zapewne zmieniłoby na korzystniejszy dla Polski ton informacji, jakie przekazywał on do ryskiego dziennika Michaiła Milruda (być może z czasem przerodziłoby się to w bliższą współpracę). W celu wzmocnienia swoich wpływów na rynku prasowym, w 1931 r. Fiłosofow próbował nakłonić znanego wileńskiego działacza mniejszościowego Borysa Pimonowa, właściciela „Nasze Wriemia” (wydawanego z dodatkiem "Siegodnia”) do połączenia jego pisma z „Za Swobodu!”69. Według Kielnicza Fiłosofow wpływał na treść materiałów publikowanych $\mathrm{w}$ wileńskim dzienniku, za pośrednictwem jego redaktora

w: Polityka narodowościowa władz polskich wobec emigracji i mniejszości rosyjskiej w latach 1926-1935. Wybór dokumentów, oprac. Ł. Dryblak, „Przegląd Wschodni” 14 (2015), nr 1, s. $228-229$.

63 AAN, MSW, 82, Sprawozdanie z życia mniejszości narodowych za II i III kwartał 1930 r., s. 75.

64 „Был составлен меморандум, объясняющий наши намерения. Философов передал его начальнику восточного отдела министерства иностранных дел Тадеушу Голувко [...] Русские эмигранты, с точки зрения международного нрава, были иностранцами, но Голувко признал, что существование их представительства будет полезно не только им, но и польской власти. Он убедил в этом министерство внутренних дел, утвердившее в 1931 году устав Российского Общественного Комитета в Польше. Его первым председателем стал Буланов, а одним из членов правления - Философов", С.Л. Войцеховский, Эпизоды, Лондон-Канада 1978, http://www.dk1868.ru/history/voytzexov.htm\#z151 (dostęp: 14.01.2014).

65 S. Kielnicz do M. Milruda, 17.12.1930, w: Л. Флейшман, Ю. Абызов, Б. Равдин, Русская печать в Риге: из истории газеты "Сегодня» 1930-х годов, t. 1-5, Stanford 1997, t. 1, s. 325.

66 Ibidem, s. 326.

67 „Я сказал, что могбы пойти толко тогда, если бы Фил[ософов] согласился предоставить мне диктаторские права и право vето на его статьи, буде я признаю их врегньеми для дела", S. Kielnicz do M. Milruda, 17.12.1930, ibidem, s. 326.

68 S. Kielnicz do M. Milruda, 12.12.1933, ibidem, t. 3, s. 160.

69 S. Kielnicz do M. Milruda, 17.12.1930, ibidem, t. 1, s. 327. 
- „Оказывается, Марков там строго выполняет инструкции Фил<ософо>ва и ведет к обеденению с За Свободу!”70. Natomiast sam Kielnicz czerpał te informacje od Gieorgija Szulgina, który był do 1931 r. jego zaufanym w redakcji „Za Swobodu"71. Fiłosofowi nie udało się nawiązać współpracy ani z Kielniczem, ani z Pimonowem. Przyczyną były różnice poglądów i niechęć obydwu do politycznego podporządkowania się Fiłosofowi. Oprócz czynników politycznych niemałą rolę odegrały kwestie finansowe i względy prestiżowe. Okazało się, że fakt współpracy zarówno Fiłosofowa, jak i Pimonowa z państwem polskim nie gwarantował porozumienia między nimi.

Możliwe, że - poprzez Wojciechowskiego - Fiłosofow próbował również szukać zbliżenia z twórcami poczytnego paryskiego dziennika „Wozrożdienije”. Być może prowadził on na ten temat rozmowy z „prawym” liberałem, profesorem Piotrem Struwe, który w 1931 r. był jednocześnie redaktorem eurazjatyckiego pisma „Rossija i Sławiaństwo”. Dzięki jego wsparciu Fiłosofow mógł liczyć na wzmocnienie propolskiej orientacji wśród emigrantów ${ }^{72}$. Wizyta Struwego w Polsce nie przyczyniła się do ożywienia współpracy prasowej (poza krótkim okresem, na przełomie lat 1934 i 1935, gdy Struwe pisał do „Miecza”) ${ }^{73}$, niemniej z innych względów warto poświęcić jej więcej miejsca.

Profesor po raz pierwszy przyjechał do Polski 22 czerwca 1926 r., oficjalnie na Międzynarodowy Kongres Nauki, a nieoficjalnie - jak sugerował Richard Pipes w związku z wszczęciem przez Piłsudskiego w maju tego samego roku dochodzenia w sprawie „Trustu"74. Wiemy, że w czasie kongresu odbyli oni jedną krótką rozmowę, która nie mogła jednak mieć większego znaczenia ze względu na obecność osób trzecich ${ }^{75}$. Po powrocie do Francji Struwe opublikował artykuł, w którym pozytywnie odniósł się do przewrotu majowego ${ }^{76}$, wpisującego się w jego koncepcję, zakładającą dobre funkcjonowanie jedynie starych demokracji; w pozostałych krajach „he tended to favour «strong men» exemplified by Marshal Pilsudski, who provided firm political leadership without depriving the citizenry of its basic civil rights, especially the right to own property"77.

Druga wizyta Struwego miała miejsce na przełomie czerwca i lipca $1931 \mathrm{r}$. Oficjalnie odbyła się w odpowiedzi na zaproszenie Rosyjskiego Komitetu

\footnotetext{
70 S. Kielnicz do M. Milruda, 18.12.1930, ibidem, s. 330.

71 S. Kielnicz do M. Milruda, 9.03.1931, ibidem, t. 3, s. 169-170.

72 AAN, MSW, sygn. IV/85, Sprawozdanie z życia mniejszości narodowych za II kwartał 1931 r., Warszawa 1931, s. 64.

73 R. Pipes, Struve. Liberal on the Right, 1905-1944, London 1980, s. 401.

74 „It is possible that Struve's trip to Poland was connected with Pilsudski's concern, and he might even have acted at Pilsudski's behest”, r. Pipes, op. cit., s. 386.

75 Ibidem, s. 387.

76 П.Б. Струве, Возвысшение Пилиудского, „Возрождение” 364 (1.07.1926), w: Дневник Политика (1925-1935), Москва-Париж 2004, s. 121-122.

77 R. Pipes, op. cit., s. 412, 414.
} 
Społecznego ${ }^{78}$ (inicjatorem zaproszenia Struwego, który przebywał wtedy na Bałkanach, miał być członek RKS, a zarazem korespondent „Wozrożdienija” i sympatyk ruchu eurazjatyckiego Siergiej Wojciechowskij) ${ }^{79}$. Działacze rosyjscy wystosowali zaproszenie, zapewne po wcześniejszym uzgodnieniu tego pomysłu $\mathrm{z}$ władzami polskimi, które zgadzając się na przybycie związanego z ruchem eurazjatyckim, jednego z bardziej znanych, szanowanych, emigracyjnych profesorów rosyjskich, miały okazję wykonać gest dobrej woli w kierunku społeczności rosyjskiej w Polsce i działaczy eurazjatyckich na świecie oraz podjąć próbę nawiązania współpracy z prominentnym działaczem rosyjskim, znanym z krytycznego stosunku zarówno do nazizmu, jak i komunizmu ${ }^{80}$.

Struwe wystąpił w Polsce na I Wszechpolskim Zjeździe Rosyjskich Organizacji Mniejszościowych i wziął udział w otwartym spotkaniu grupy dyskusyjnej (Литературное содружество), któremu przewodniczył Fiłosofow. Grupa ta sympatyzowała z nowopokoleńcami, ich trybuną był dodatek do „Za Swobodu!” - „W swoim ugłu”. Według Wiktora Bajdałakowa ${ }^{81}$, podobne dodatki wychodziły również $\mathrm{w}$ ramach popularnych wśród nowopokoleńców pism „Rosja i Słowiaństwo”, red. P. Struwe (1928-1934 Paryż) oraz „Russkij Gołos”, red. W. Pronin (Belgrad 1931-1941) ${ }^{82}$ - niezwykle ciekawym byłoby zbadanie narracji obu tych tytułów względem Polski oraz stopnia zainteresowania nimi przez „dwójkę". Profesor wygłosił również cykl cieszących się ogromną popularnością odczytów w Warszawie, Wilnie i Grodnie na temat niemożności zrealizowania sowieckiego planu pięcioletniego oraz stosunków polsko-rosyjskich. Jego wystąpienia mogły wydatnie wspomóc prowadzoną akcję pozyskiwania Rosjan przez obóz rządzący; mówił on m.in. „iż myśl o niepodległości Polski była zawsze niezbędnem ogniwem w systemie światopoglądu politycznego całej przedrewolucyjnej przodującej inteligencji rosyjskiej, przyczem na zakończenie oświadczył: „«Nie jestem powołany mówić w imieniu całej emigracji rosyjskiej o stosunkach rosyjsko-polskich, muszę jednak stwierdzić, że narodowa Rosja, która przyjdzie po upadku ustroju komunistycznego, nie będzie miała celów agresywnych, lecz zajmie się

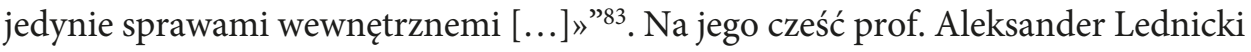
wydał śniadanie, na którym obecni byli liczni uczeni oraz kierownik Wydziału

78 AAN, MSW, sygn. IV/85, Sprawozdanie z życia mniejszości narodowych za II kwartał 1931 r..., s. 63-64; Richard Pipes odnotował jedynie w kalendarium życia Struwego, że w czerwcu i lipcu 1931 r. odbył on podróż do Warszawy, Berlina i Pragi; r. Pipes, op. cit., s. 465.

79 Сочинения русского периода, t. 1: Стихотворения и поэмы, ред. Л. Флейшман, Москва 2011, s. 107.

${ }^{80}$ R. Pipes, op. cit., s. 414.

81 W. Bajdałakow (1900-1967), w wieku 18 lat wziął udział w wojnie domowej po stronie „białych”, razem $\mathrm{z}$ wojskami Wrangla ewakuował się do Jugosławii, gdzie ukończył wydział chemii na Uniwersytecie Belgradzkim, był organizatorem NSRM, od 1931 r. prezesem NSNP, a następnie NTS.

82 В.М. Байдалаков, op. cit., s. 10.

83 AAN, MSW, sygn. IV/85, Sprawozdanie z życia mniejszości narodowych za II kwartał 1931 r..., s. 63 i 64 . 
Wschodniego MSZ Tadeusz Schaetzel. W czasie pobytu Struwego i po jego wyjeździe z Polski w „Wozrożdieniju” i „Za Swobodu!” ukazało się kilka artykułów utrzymanych w przychylnym dla Polski tonie ${ }^{84}$.

Jak już wspominaliśmy, od 1928 r. Hołówko dążył do utworzenia propaństwowej, wpływowej, ilustrowanej gazety rosyjskiej ${ }^{85}$. Taka możliwość zaistniała po utworzeniu Rosyjskiego Komitetu Społecznego - koalicyjnej organizacji emigrantów rosyjskich, którzy postanowili założyć nowy dziennik, mogący zastąpić „Za Swobodu!”. Nim do tego doszło, w „Za Swobodu!” zaczął ukazywać się dodatek zatytułowany „Obiedinienije”, w którego kolegium redakcyjnym zasiadali członkowie zarządu RKS: Władimir Brandt, Nikołaj Bułanow, Pantelejmon Simanski, Dimitrij Fiłosofow i Aleksandr Chiriakow. Nowy dziennik ukazał się dopiero ok. osiem miesięcy po zabójstwie Hołówki ${ }^{86}, 6$ kwietnia 1932 r. W tym samym roku doszło do podziału wewnątrz RKS i wystąpienia z niego działaczy związanych z Fiłosofowem, który pokłócił się z Siergiejem Wojciechowskim, m.in. o interpretację polskiej polityki zagranicznej, a konkretnie o polsko-sowiecki pakt o nieagresji. Wojciechowski zaatakował również mniejszościową Rosyjską Organizację Młodzieżową za ugodową postawę jej członków wobec ZSRS. W obronie młodzieży stanęła redakcja „Mołwy”, krytykując jednocześnie Wojciechowskiego za jego prohitlerowskie nastawienie ${ }^{87}$. Jego oskarżenia doczekały się również odpowiedzi

84 Д.В. Филосо́фов, П.Б. Струве, „За Свободу!” 166 (26.06.1931); А.F., Доклад, П.Б. Струве, „За Свободу!” 167 (27.06.1931); П.Б. Струве в „Своем Углу”, „За Свободу!” 172 (3.07.1931); В. Клементьев В литературном содружестве. Беседа о втором и третьем поколении в емиграции. П.Б. Струве председателствовал на заседании, „За Свободу!” 175 (6.07.1931); П.Б. Струве, Письмо в редакиию, „За Свободу!” 178 (9.07.1931).

85 O powstaniu RKS i „Mołwy”: „Возникновение этой коалиции предрешило судьбу газеты, основанной Савинковым, но ее замена новой, названной «Молва», стала возможной не сразу. Нужно было договориться о программе, о редакции, сотрудниках и типографии. Подразумевалось само собой, что Философов останется издателем. Вероятно, не без помощи Голувки ему удалось получить согласие распространенной польской газеты «Экспресс Поранны» на использование ее великолепных, только что доставленных из Дрездена ротационных машин, позволивших украсить газетные листы новинкой - цветными иллюстрациями", С.Л. Войцеховский, Эпизодыл..., http://www.dk1868.ru/history/voytzexov.htm\#z151 (dostęp: 14.01.2014).

86 Prasa rosyjska bardzo ostro potępiła mord na Hołówce: Rosjanie, „Sprawy Narodowościowe”, nr 4-5 (1931), s. 478; Fiłosofow poświęcił mu długi artykuł pożegnalny, przybliżając jego sylwetkę i działalność: „[...] для покойнаго «Пана Тадеуша» в особенности, Польша мыслилась не как государство чисто этнографическое. Для Голувки, первыя строфы «Пана Тадеуша» - «Литва отчизна моя... » были самой жисой реальностью, отнюдь не художественным образом. [...] Но сделавшись слугою государства, он не сделался чиновником. И в этом была его сила, его обаятельность. План грандиознаво храма «братцтва народов» был у него всегда перед глазами. [...] Если бы я составлял проект этого памятника, я бы сделал его очень простым. Высокая, поставленная стоймя, каменная плита, а на ней надпись: «Борцу за братство народов.»", Д.В. Филосо́фов, Памяти «Пана Тадеуша», „За Свободу!” 236 (6.10.1931).

87 W. Skrunda, Rosyjska „Mniejszościowa” Organizacja Młodzieżowa w Polsce międzywojennej (ROM). Okoliczności powstania, „Studia Rossica” 5 (1997), s. 171. 
prezesa Nikołaja Szumlina ${ }^{88}$, którego poglądy wynikały nie z sympatii do ZSRS, lecz z lojalistycznej postawy wobec państwa polskiego ${ }^{89}$.

Władze polskie wykorzystywały wpływy w poczytnych pismach rosyjskich nie tylko do zwalczania agitacji komunistycznej, ale także do inspirowania rosyjskojęzycznej opinii publicznej, również za granicą ${ }^{90}$.

Należy przy tym podkreślić, że Fiłosofow, wbrew opinii jego rosyjskich przeciwników politycznych, współpracował z Polakami ze względów ideowych, a nie finansowych, jak klasyczni agenci. Mimo finansowej zależności od państwa polskiego utrzymywał on poglądową niezależność, nie zawsze zgadzał się z polityką narodowościową i wyznaniową prowadzoną przez piłsudczyków ${ }^{91}$, a w zasadzie ubolewał nad jej brakiem - „U was w Polsce, są dwa «obozy». Jedni mówią: są Ukraińcy, Białorusini, Rosjan nie ma. Dla Ukraińców i Białorusinów jesteśmy gotowi zrobić wiele. Jednak - nie robi się nic. Drudzy mówią: są tylko Rosjanie. Ale dla Rosjan nic się nie robi”92. Fiłosofow był najwytrwalszym rycerzem „trzeciej" Rosji - antyimperialnej, antybolszewickiej, demokratycznej, szanującej prawa mniejszości, dlatego w swojej pracy koncentrował się na poprawie stosunków polsko-rosyjskich oraz tępił wszelkie przejawy szowinizmu zarówno wśród Rosjan, jak i innych narodowości ${ }^{93}$. W komentowaniu sytuacji politycznej starał się zachować obiektywizm, apelując o łagodzenie konfliktów narodowościowych między Polakami, Ukraińcami i Rosjanami, które - jego zdaniem - mogły jedynie przynieść korzyść bolszewikom.

Wydaje się, że dla władz polskich rok 1931 był przełomowy jeśli chodzi o pozyskiwanie wpływów zarówno wśród mniejszości, jak i emigracji rosyjskiej, wśród której RKS - utworzony dzięki Fiłosofowowi - jako organizacja koalicyjna zyskał duże poparcie Rosjan ${ }^{94}$.

${ }^{88}$ N. Szumlin, prezes ROM, według materiałów Wojskowej Służby Wewnętrznej był on agentem Oddziału II oraz jednocześnie niemieckiego wywiadu wojskowego, AIPN BU, 2386/16886, Szefostwo WSW 1960-1963, Informacja dotycząca genezy i działalności org. Narodowego Związku Pracy. NTS, Warszawa X 1961 r., k. 67.

89 „«Dążymy - stwierdził Szumlin - do utworzenia z miejscowej ludności rosyjskiej mniejszości idealnej, świadomej swej odrębności kulturalnej, ale jednocześnie popierającej gorąco wszelkie dążenia większości do umocnienia potęgi państwa polskiego»", cyt. za: W. Skrunda, op. cit., s. 168.

90 Zob.: Ł. Dryblak, Inspiracja i formy wspótpracy polskich instytucji państwowych $z$ wydawcami $i$ redakcjami pism rosyjskich w latach 1919-1935 - zarys problematyki, „Dzieje Najnowsze” 48 (2016), nr 1, s. 33-52.

91 Przykładowe artykuły utrzymane w krytycznym tonie: Д.В. Филосо́фов, Ядовитые иветь, „За Свободу!” 187 (17.08.1926); Русификация, „За Свободу!” 217 (20.09.1926).

${ }^{92}$ Listy Dymitrija Fiłosofowa do Mariana Zdziechowsiego, oprac. P. Ławriniec, „Zeszyty Historyczne” 168 (2008), s. 185-186.

93 Д.В. Филосо́фов, Единый православный фронт, „За Свободу!” 264 (7.12.1928).

94 AAN, MSW, sygn. IV/86, Sprawozdanie z życia mniejszości narodowych za III kwartał 1931 r., Warszawa 1931, s. 50. 


\section{NTS - powstanie i współpraca z Referatem „Wschód”}

Związek, który przekształcił się w NTS, powstał z połączenia rosyjskich organizacji młodzieżowych z Bułgarii i Jugosławii w NSRM (Национальный Союз Русской Молодежи за Рубежом $)^{95}$. W 1930 r. odbył się I Zjazd Związku, na którym doszło do przyłączenia kolejnych organizacji młodzieżowych. W następnym roku miał miejsce II Zjazd, na którym obecni byli przedstawiciele z siedmiu państw, w tym z Polski w osobie Aleksandra Würglera (znakiem rozpoznawczym, wysiadających na peronie delegatów była eurazjatycka gazeta „Rossija i Sławiaństwo”) ${ }^{96}$. Był to jeden z ważniejszych zjazdów. Przyjęto na nim nową nazwę organizacji (Национальный Союз Нового Поколения), uchwalono program, wybrano władze - prezesem zarządu w Belgradzie został Wiktor Bajdałakow, a przewodniczącym rady, z siedzibą w Paryżu, książę Siergiej Leuchtenberski; ustalono również, że członkiem może być tylko osoba urodzona po $1895 \mathrm{r} \cdot{ }^{97}$ Starsi musieli uzyskać pozwolenie Biura Wykonawczego - w ten sposób chciano uniknąć sporów partyjnych, którymi tak bardzo przesiąknięte było rozpolitykowane starsze pokolenie ${ }^{98}$.

Trudno określić, kiedy miały miejsce pierwsze kontakty polskich emigrantów z organizacjami młodzieżowymi na Bałkanach; hipotetycznie sposobność ku temu dawał Zjazd Rosyjskich Pisarzy w Belgradzie w 1928 r., w którym uczestniczyli reprezentanci Związku Rosyjskich Pisarzy i Dziennikarzy w Polsce - prezes Siergiej Kielnicz i Anatol Wielmin (chociaż raczej żaden z nich nie został członkiem NTS-u $)^{99}$. Prawdopodobnie w tym samym roku do związku wstąpił Aleksandr Würgler; być może już wtedy był on związany z nowopokoleńcami. Możliwe, że przybył z zadaniem pozyskania dla nich nowych sympatyków. Działając w Związku

95 А.В. Окороков, Русская эмиграция, Москва 2003, s. 47.

96 А. Вюрглер, На II-ом съезде Нац. Союза Нового Поколения (б. НСРМ), „За Свободу!” 4 (6.01.1932), s. 6.

Aleksander Würgler (1901-1943), w 1920 r. wyjechał do Szwajcarii (posiadał szwajcarskie obywatelstwo), w 1923 r. zaczął studia w Rosyjskim Instytucie Ekonomicznym, w 1928 r. uzyskał tytuł doktora nauk ekonomicznych, następnie wyjechał do Polski i wstąpił do Związku Rosyjskich Pisarzy i Dziennikarzy; w 1931 r. był delegatem na Zjeździe NSRM; w 1934 r. uczestniczył w III Zjeździe i został członkiem Biura Wykonawczego; był szefem polskiego oddziału NTS, współpracował z wywiadem japońskim poprzez attaché Japonii gen. Sawadę oraz z szefem Referatu „Wschód” Oddziału II SG kpt. Jerzym Niezbrzyckim; w czasie wojny światowej podjął współpracę z gen. Sonderstabu „R” Borisem Smysłowskim, oficerem Abwehry; dzięki współpracy z Siergiejem Wojciechowskim, prezesem Rosyjskiego Komitetu w Warszawie, prowadził nielegalny przerzut członków NTS na okupowane przez Niemców tereny rosyjskie; prawdopodobnie była to jedna z przyczyn (obok kontaktów z polskim podziemiem) jego zamordowania przez agenta gestapo w 1943 r. (swój udział w morderstwie miało również NKGB); И.В. Грибков, Д.А. Жуков, И.И. Ковтун, Особый штаб „Россия”, Москва 2011, s. 81, 84, 92, 100; В.М. Байдалаков, op. cit., s. 83.

97 А. Вюрглер, На ІІ-ом съезде..., s. 6.

98 Ibidem.

99 AAN, MSW, sygn. 1932, k. 41-46. 
Rosyjskich Pisarzy i Dziennikarzy (Союз русских писателей и журналистов в Польше), musiał zetknąć się z Fiłosofowem - antybolszewizm, antytotalitaryzm, poszanowanie dla innych narodowości, federacjonizm, w pewnym stopniu demokracja, aktywizacja młodych - to główne elementy, które mogły umożliwić nawiązanie współpracy między nimi. Chociaż nie wiemy, kiedy Referat „Wschód” wszedł w kontakt $\mathrm{z}$ nowopokoleńcami i czy to on patronował spotkaniu Fiłosofowa z Würglerem, czy też to Fiłosofow skontaktował Würglera z Oddziałem II, pewne jest, że musiało się to odbywać za wiedzą i przyzwoleniem kierownictwa „dwójki”.

Jak już wspomnieliśmy, nowopokoleńcy byli ruchem młodzieżowym, a właśnie na młodzież stawiał w swojej pracy Fiłosofow. Jednym z większych problemów rosyjskiej diaspory było starzenie się jej członków; młodzi Rosjanie byli coraz mniej czuli na problemy emigracji, coraz mniej interesowali się sytuacją w Związku Sowieckim, a nawet ulegali asymilacji, co dotyczyło szczególnie tych Rosjan, którzy weszli w związki mieszane narodowościowo oraz zdobyli obywatelstwo polskie. Problemy te były przedmiotem troski Fiłosofowa, który przeciwdziałał im nie poprzez antypolską propagandę, jak niektóre skrajnie prawicowe kręgi rosyjskie na Kresach, lecz stawiając emigracji rosyjskiej za wzór polską Wielką Emigrację ${ }^{100}$ - „Сколько надо сознательности, мужества и сил, чтобы бороться с коммунизмом и с шовинизмом, и в этой борьбе не забывать о ежедневной работе в «огороде». Русской эмигр<антской> молодежи (и там, в России!) надо заражаться психологией Мицкевичей [...]"101. W celu aktywizacji młodych, udostępnił im w listopadzie 1927 r. miejsce na łamach "Za Swobodu!", wydając dodatek „Jedinienije”, który miał stać się platformą do wymiany poglądów rosyjskiej młodzieży ${ }^{102}$. W styczniu 1930 r. w „Za Swobodu!” pojawił się kolejny dodatek skierowany do młodych - „W swojem ugłu”; a w skład jego kolegium redakcyjnego weszli Władimir Brandt ${ }^{103}$, Antoni Dąbrowski ${ }^{104}$,

100 A. Nowak, Dymitr Fiłosofow: dyskusja z polska „mickiewiczologia” czy z polskim kompleksem?, w: Akademie nauk, uniwersytety, organizacje nauki, polsko-rosyjskie relacje w sferze nauki XVIII$X X$ w., red. L. Zasztowt, Warszawa 2013, s. 344.

101 D. Fiłosofow do St. i J. Stempowskich, 14.07.1930, Warszawa (oryginał w Oddziale Rękopisów BUW), От эстетики к этике. Из переписки Д.В.Философова. 1920-1932, „Наше Наследие” 63-64 (2002), http://www.nasledie-rus.ru/podshivka/6407.php (dostęp: 9.04.2015).

102 От редакционной коллегии, „За Свободу!”, 273, (27.11.1927).

103 W.W. Brandt (1892-1942), ppłk Armii Ochotniczej, współpracownik Oddziału II SG, członek Ludowego Związku Obrony Wolności i Ojczyzny, Bractwa Ruskoj Prawdy, „Tawerny Poetów”, grupy literackiej „Litieraturnoje Sodrużestwo”, współpracownik „Za Swobodu!”, członek komitetu redakcyjnego „Mołwy”; po odejściu Fiłosofowa, współredaktor naczelny „Miecza”, nieoficjalnego organu NTS, organizator tajnej „szkoły” dla działaczy NTS pod Warszawą; И.В. Грибков, Д.А. Жуков, И.И. Ковтун, ор. cit., s. 90; Т.Д. Исмагулова, Русская эмиграция в Польше (Владимир Бранд - поэт и воин „русской Варшавы”), w: Зарубежная Россия 1917-1939 г2., ред. В.Ю. Черняев, Санкт-Петербург 2003, s. 347-350; Ł. Ulatowski, op. cit., s. 26.

104 A.S. Dąbrowski (1889-1938), ur. w guberni woroneskiej, zm. w Warszawie, b. oficer, uczestnik I wojny światowej, członek „Litieraturnogo Sodrużestwa”, współpracownik licznych gazet, w tym „Za Swobodu!”, http://www.mochola.org/russiaabroad/ruspldb/ruspl_c.htm (dostęp: 11.04.2015). 
Wasilij Klemientiew ${ }^{105}$ i Nikołaj Riazancew ${ }^{106}$, którzy z czasem ujawnili się jako sympatycy NSRM. 30 kwietnia 1931 r. ukazał się pierwszy numer dodatku, obszernie informujący o działalności NSRM, autorstwa jego przedstawiciela w Polsce Aleksandra Würglera ${ }^{107}$.

Na przełomie 1931 i 1932 r. odbył się II Zjazd NSRM w Belgradzie. Polski oddział reprezentował na nim Würgler, który zrelacjonował jego przebieg na łamach „W swojem ugłu” i poinformował o założeniu nowego związku pod nazwą Narodowy Związek Nowego Pokolenia ${ }^{108}$. Pisząc o zadaniach Związku, wyróżnił jako główne konieczność utworzenia „Wielikoj Rossii”, przez co uważał za potrzebne wzniecenie narodowej rewolucji i ustanowienie dyktatury na czas przejściowy. Postulował również zjednoczenie wszystkich organizacji antykomunistycznych, walkę z teorią ewolucji systemu bolszewickiego, przeciwdziałanie wynaradawianiu Rosjan poprzez organizacje społeczne i kulturalne oraz przygotowanie kadr rewolucyjnych. Artykuł zakończył ogłoszeniem skierowanym do zainteresowanych ruchem, by zgłaszali się do kolegium redakcyjnego „W swojem ugłu”. W tym samym numerze opublikowano założenia ideologiczne NSNP: 1. powołanie silnej władzy centralnej, ponadklasowej i ponadpartyjnej; 2. ustanowienie swobód obywatelskich, równości wobec prawa, zniesienie przywilejów klasowych oraz stanowych; 3. „Zachowanie w polityce wewnętrznej zdrowego egoizmu narodowego [...].", w polityce zagranicznej dążenie do możliwie ścisłej współpracy kulturalno-politycznej ze Słowianami; 4. „Uznanie prawa do narodowego samostanowienia dla narodów wchodzących w skład Rosji”; 5. rozwiązanie kwestii agrarnej; 6. wprowadzenie wolności ekonomicznej, ograniczanej jedynie w interesie państwa ${ }^{109}$. Charakteryzując poglądy nowopokoleńców, warto odnieść się do londyńskich wykładów Wiktora Sukiennickiego, teoretyka prawa, sowietologa i znawcy tematyki rosyjskiej, który określił ich jako demokratów, zwolenników ustroju federacyjnego, ale nie rozczłonkowania Rosji ${ }^{110}$.

Polska gałąź NSNP miała liczne oddziały terenowe (najwięcej na Kresach) ${ }^{113}$, w połowie lat trzydziestych liczące - zdaniem sekretarza generalnego Michaiła

105 W.F. Klemientiew, prozaik, członek Litieraturnogo Sodrużestwa, publicysta gazet: „Za Swobodu!”, „Mołwa” i „Miecz”.

106 N.A. Riazancew (1907-?) ur. w Kowlu, członek grupy „W swojem ugłu” i kolegium redakcyjnego dodatku o tej samej nazwie, członek Litieraturnogo Sodrużestwa; na początku lat 30. wyjechał do Francji; studiował chemię, uczestniczył w spotkaniach „Zielonej Lampy”, http://www.dommuseum.ru/index.php?m =dist\&pid=12492\&PHPSESSID $=$ da6e293f80df7744931d451004f6ae4b (dostęp: 11.04.2015).

107 А. Вюрглер, Н.С.Р.М., „За Свободу!” 114 (30.04.1931).

108 Idem, На II-ом съезде..., „За Свободу!” 4 (6.01.1932).

109 Ibidem.

110 W. Sukiennicki, Trzydzieści lat emigracji rosyjskiej, Londyn 1950, s. 14.

111 „До 1939 года Польский отдел был одним из наиболее крупных Отделов НТС”, Я. Трушнович, К истории Нородно-Трудового Союза, „Посев” 7 (2000), http://www.posev.ru/files/ nts-about/ne7006.htm (dostęp: 9.04.15). J. Trusznowicz, syn Aleksandra (1893-1954), znanego 
Gieorgijewskiego - około 150 członków $^{112}$, co stawiało polski oddział na trzecim miejscu w Europie ${ }^{113}$. Według Stanisławskiego jego członkowie werbowali nie tylko emigrantów lecz również członków mniejszościowej ROM, Ukraińców, Kozaków i innych, zakładając na terenie Rzeczypospolitej 14 oddziałów ${ }^{114}$, m.in. w Warszawie, Łodzi, Wilnie, Lwowie, Sosnowcu, Kaliszu, Brześciu nad Bugiem ${ }^{115}$. Bardzo możliwe, że przykrywką dla działań NSNP był ROM, który rozpościerał swoje wpływy również na Związek Rosyjskich Studentów oraz seminaria prawosławne w Warszawie i Krzemieńcu, a także uniwersytety i szkoły średnie (w tym Szkołę Wawelberga), w których uczyli się Rosjanie ${ }^{116}$. Za pośrednictwem prasy ${ }^{117}$, spotkań i odczytów, werbowano nowych członków (na Kresach, musiało to odbywać się za zgodą organów państwowych, gdyż Rosjanie niemieszkający w województwach wschodnich musieli mieć specjalne pozwolenie na przemieszczanie się po ich terenie - przykład Władimira Brandta ${ }^{118}$ ) i przeciwdziałano denacjonalizacji młodzieży rosyjskiej. We wszystkich relacjach działaczy NTS, do których udało się nam dotrzeć, ocena działalności polskiej sekcji wypadała bardzo dobrze; podkreślano również jej świetne zakonspirowanie i dobrą współpracę z Polakami ${ }^{119}$. Skala działalności NSNP/NTS z trzech względów jest zaskakująca i zasługuje na szczególną uwagę. Po pierwsze, tolerowanie werbunku osób narodowości nierosyjskiej musiało się kłócić z działalnością Ekspozytury II Oddziału II SG; po drugie administracja terytorialna $\mathrm{z}$ reguły patrzyła nieprzychylnie na inicjatywy podejmowane wspólnie przez mniejszość i emigrację rosyjską, gdyż opóźniało to asymilację Rosjan; po trzecie działalność NTS we wschodnich województwach wymagała specjalnych pozwoleń od wojewodów (emigranci nie mogli się po nich swobodnie poruszać) oraz przełamania ich niechęci i z każdym rokiem zmniejsza-

działacza NTS, zamordowanego przez KGB; za pośrednictwem polskiej placówki dyplomatycznej wyjechał wraz z ojcem i matką z ZSRS do Jugosławii, po wojnie zamieszał w RFN; działacz NTS, publicysta i redaktor pisma „Posiew”.

112 Из протоколов допросов лидера Национально-Трудового Союза Нового Поколения М.А. Георгиевского, w: Политическая история русской эмиграции 1920-1940 гг. Документыь и материалы, ред. А.Ф. Киселев, Москва 1999, http://www.russky.com/history/library/emigration/emigration3.htm\#290 (dostęp: 27.04.2015).

113 W. Stanisławski, Myśl polityczna..., s. 201.

114 Ibidem, s. 202, przyp. 222.

115 AIPN BU, 2386/16886, Informacja..., k. 68; В.М. Байдалаков, op. cit., s. 18.

116 AIPN BU, 2386/16886, Informacja..., k. 68.

117 Temat młodzieży, jak już wspomnieliśmy, był często poruszany przez Fiłosofowa, ale również przez jego młodszych współpracowników z „W swoim ugłu”, А. Домбровский, Молот и стекло, „За Свободу!” 265 (5.10.1931); В. Брандт, Чёрная работа, „За Свободу!” 230 (31.08.1931); И. Метелица, Борьба с денационализацей, „За Свободу!” 298 (10.11.1931).

118 Т.Д. Исмагулова, ор. cit., s. 350.

119 Б. Прянишников, Новопоколенцьь, Мэриленд 1986, s. 98; Е. Дивнич, NTS, Нам пора объясниться!, Нью-Йорк 1968, s. 36; „Wiedziałem, że sekcja NTS w Polsce była liczna i dobrze zorganizowana. Ale nie miałem pojęcia, że panuje w niej atmosfera takiej tajności i konspiracji”, A. Stołypin, Cesarstwo i wygnanie, tłum. P. Hertz, Warszawa 1998, s. 209, 199-200. 
jącej się tolerancji dla działalności organizacji rosyjskich (taka postawa dotyczyła szczególnie wojewody poleskiego Wacława Kostka-Biernackiego i wołyńskiego Henryka Józewskiego).

Po zamknięciu „Za Swobodu!” nowopokoleńcy publikowali w „Mołwie”, której wydawcą był Władimir Brandt, a redaktorem odpowiedzialnym Nikołaj Riazancew. W maju 1934 r. miejsce „Mołwy” zajął tygodnik „Miecz”, kierowany przez komitet redakcyjny w składzie: przewodniczący Fiłosofow, sekretarz Leon Gomolicki oraz członkowie Eugenia Weber-Chiriakowa, Gieorgij Sokołow oraz wydawca i redaktor odpowiedzialny - Antoni Dąbrowski. Był to międzynarodowy projekt Fiłosofowa - równolegle wychodziło paryskie wydanie „Miecza” pod redakcją Mereżkowskiego. Pisywali w nim znani intelektualiści rosyjscy, m.in. z Polski, Francji (Gippius i Mereżkowski) i Czechosłowacji (Alfred Bem). Współpraca ta, w wyniku nieporozumień między Mereżkowskim a Fiłosofowem, została zerwana we wrześniu 1934 r. ${ }^{120} \mathrm{~W}$ ostatnim artykule Fiłosofow ogłosił przekazanie pisma młodszemu pokoleniu, a nowymi redaktorami zostali Brandt i Sokołow. W wyniku fiaska idei „Miecza” jako ogólnoeuropejskiego tygodnika jednoczącego rosyjskich pisarzy, Fiłosofow zwrócił się w kierunku polskich intelektualistów. W listopadzie 1934 r. odbyło się pierwsze zebranie grupy dyskusyjnej „Domik w Kołomnie”, któremu przewodniczył jako „starszina” ${ }^{21}$. Spotkania miały zazwyczaj charakter rosyjsko-polski (wśród gości dominowali Polacy), ale czasami bywali na nich przedstawiciele innych narodowości, na przykład Ukraińcy. Na początku 1936 r. stan zdrowia „starsziny” pogorszył się, w kwietniu poddał się on kuracji w Otwocku, gdzie zmarł 5 sierpnia 1940 r. w „Wiktorówce”, pod opieką doktor Zofii Dobrowolskiej ${ }^{122}$.

Artykuły ukazujące się na łamach „Mołwy”, a następnie „Miecza” miały dwa ostrza: antyniemieckie i antysowieckie ${ }^{123}$ - ogólnie antytotalitarne ${ }^{124}$; ich autorzy poszukiwali trzeciej drogi, która pozwoli im odzyskać ojczyznę, szukali wsparcia innych krajów ${ }^{125}$. Byli zdania, że wszelka agresja na ZSRS, również japońska, powinna otrzymać wsparcie emigracji - ich zdanie podzielała większość emigrantów rosyjskich w Warszawie, w przeciwieństwie do nielicznych warszawskich sympatyków

120 Д.В. Филосо́фов, К. Читателям, „Меч” 19-20 (23.09.1934), s. 3-4.

121 P. Mitzner, Warszawski „Domek w Kołomnie”, Warszawa 2014, s. 64.

122 Ibidem, s. 91.

123 Д.В. Филосо́фов, Восточноевропэйская конвенция, „Молва” 153 (8.07.1933); „Мы должны сказать себе раз на всегда, что сов. правительство не может эволюционировать” В. Брандт, Тактический ход, „Меч” 8 (24.06.1934), s. 8-9; Artykuł wstępny nowej redakcji, „Меч” 21 (7.10.1934), s. 1.

124 Д.В. Филосо́фов, Десять тет фашизма, „Молва” 172 (29.10.1932).

125 „Эмиграция считает возможным «третий путь», видя в Японии естецственнаго союзника Национальной России и считать, что жизненные интересы Японии требуют сознания Национальной России и союза с Ней. Совершенно верно говорит «Знамия России». [...] Благодетельным для обоих империй является лишь третий путь”, В. Брандт, Национальная Россия и япония, „Меч” 42 (24.10.1935), s. 4. 
grupy Milukowa, uważających takie postępowanie za zdradę ${ }^{126}$. Zwalczali inspirowany przez Sowietów ruch „Smienowiechowców” i „Mładorosów” Aleksandra Kazembeka wywodzące się ideologii eurazjatyckiej ${ }^{127}$, faszystów z Rosyjskiego Wyzwoleńczego Ruchu Ludowego (Российское Освободительное Национальное Движение), powstałego w Niemczech w kwietniu 1933 r. ${ }^{128}$ oraz przywódcę kozaków na Dalekim Wschodzie atamana Grigorija Siemionowa ${ }^{129}$.

W swoich artykułach nie komentowali polityki polskiego rządu ani nie angażowali się w sprawy mniejszości, chociaż ich wezwania były skierowane do wszystkich Rosjan, w szczególności do młodzieży. Wielokrotnie manifestowali swoją lojalność wobec państwa polskiego, zamieszczając liczne informacje i zdjęcia z uroczystości państwowych i świąt, szczególnie fetując marszałka Józefa Piłsudskiego ${ }^{130}$. Należy zwrócić uwagę, iż emigranci, być może nawet nie do końca świadomie, często wzorowali się w swojej działalności na obozach rządzących w krajach, w których się znajdowali. Oczywiście, zdarzało się, że ich działania były inspirowane przez gospodarzy danego kraju. Również w Polsce możemy dostrzec pewną fascynację obozem piłsudczyków, czego wyrazem był kilkakrotnie przywoływany przez Fiłosofowa pomysł utworzenia „Ordiena Biednych Rycariej” (określenia tego użył on w stosunku do grupy „Swojego Ugła”) ${ }^{131}$, koncepcja przejściowej dyktatury autorstwa Würglera czy artykuł z okazji imienin Piłsudskiego - „[...] Mbl эмигранты с особой ясностью осознаем, какое значение имеет вождь"132. Oczywiście, nie wiadomo, na ile było to spowodowane funkcjonowaniem w środowisku polskim, a na ile ogólnoeuropejskim trendem, utrzymującym się szczególnie wśród młodzieży - „Różniąc się podobnie jak ich «ojcowie» w często istotnych

126 AAN, MSW, sygn. IV/88, Sprawozdanie z życia mniejszości narodowych za I kwartał 1932 r., Warszawa 1932, s. 53.

127 Д.В. Филосо́фов, Где бюро меньшинств, „Молва” 84 (11.04.1933); В.М. Байдалаков, op. cit., s. 8 .

128 „ «ОНД» и т.п. организации - явление печальное и даже позорное. Но еще печальнее и еще позорнее, забывать свои основной долг по отношению к родине [...]”, А. Вюрглер, О задачах эмиграции, „Молва” 123 (31.05.1933).

129 В. Брандт, Национальная Россия..., s. 4.

130 Bardzo dużo miejsca poświęcono śmierci marszałka - „И мы русские эмигранты в Польше, навсегда сохраним благодарную память о той огненной ненависти с которою Он относился ко всему тому, подлому и лицемерному - ко всему тому, что заставило нас покинуть нашу родину и принять протянутую руку братского полскаго народа”, Кончина Маршала, „Меч” 53 (19.05.1935), s. 1.

131 „Моему сердцу всего ближе группа Своего угла, и я тихо радуюсь, что именно она одухотворяет новую газету. Пользуюсь последней возможностью указать этой группе „бедных рыцарей” свою искреннюю признательность за ту неустанную моральную поддержку которую она оказывала прекращающейся ныне газете”, Д.В. Филосо́фов, Прощальная станция, „За Свободу!” 75 (3.04.1932), s. 2; idem, „От чего зависит возрождение эмиграции? Доклад, прочитанный 18 марта 1934 г. на собрании «Литературного Содружества»”, „Меч” 5 (3.06.1934), s. 9.

132 Непоколебимыцй, „Меч” 44 (19.03.1935), s. 1. 
szczegółach «młodzi» zgodnie wzdychali do «genialnego wodza», który by potrafił skupić i zorganizować wszystkie aktywne siły «żywe siły» narodowe i obalenie materialistycznego, bezbożnego, internacjonalistycznego bolszewizmu odbudować potężny i wspaniały gmach «Rossyjskiego» («stunarodowego» i «stujęzycznego», a nie tylko «Wielkorosyjskiego») Imperium"133.

\section{Droga do wojny}

Wybiegając poza ramy chronologiczne artykułu, należy skonstatować, że kontakty polsko-rosyjskie z drugiej połowy lat trzydziestych wciąż oczekują na gruntowne przebadanie. Obecnie wiadomo, że był to okres intensyfikacji współpracy między NTS a Oddziałem II SG. Wśród zaangażowanych oficerów zapewne ważną rolę pełnił, wymieniany w wielu wspomnieniach rosyjskich, szef Referatu „Wschód” kpt. Jerzy Niezbrzycki ${ }^{134}$. Najdłuższy opis spotkania z Niezbrzyckim zawarł w swej relacji Brżestowskij, gdzie napisał on między innymi: „Раз к нам в класс пришёл началник школы - шеф «реферат всхуд» и, кажется, инициатор сотрудничества с НТС, по фамилии, на сколко сейчас помню, Врага. Поздоровавшись с нами, сказал, как он рад, что традиционное русское сопротивление силе зла продолжается, что теперь представителей етого сопротивления он видит в НТС и в нас и что-то ещё в етом духе"135. Kłóci się to z ustaleniami Łukasza Ulatowskiego, który stwierdził, że „z usług wywiadowczych samych Rosjan, białych, Niezbrzycki korzystał nader niechętnie. Z gruntu odrzucał podjęcie głębszej współpracy z emigracją. [...] Kontakty referatu „Wschód” z emigrantami, jednostkami, tliły się jedynie poprzez całe lata trzydzieste"136. Autor przyznaje, że niewielka liczba „białych” pracowała dla Oddziału II, jednakże dodaje, że z braku dostępnych dokumentów oraz relacji problem ten „nie doczekał się dotychczas należytego naświetlenia"137. Większość dokumentów Oddziału II, przechowywana w Rosyjskim

${ }^{133}$ W. Sukiennicki, op. cit., s. 10. Spośród innych mniejszości Piłsudski cieszył się szczególnym kultem wśród członków młodzieżowej, syjonistycznej, żydowskiej organizacji „Betar”, podobnie jak NTS, korzystającej ze wsparcia ze strony państwa.

134 Kpt. J. Niezbrzycki, w latach 1932-1939 szef Ref. „Wschód”, we wrześniu 1939 r. wydelegowany przez szefa sztabu Naczelnego Wodza „do rozmów z wywiadem rumuńskim, od którego uzyskał zgodę na tolerowanie działalności polskiego wywiadu (Ekspozytura «R»). Sam, obciążony współpracą z sanacją, nie uzyskał funkcji w Oddz. II Szt. NW", Załacznik do sprawozdania z działalności Oddziału II Sztabu Głównego, oprac. T. Dubicki, A. Suchcitz, w: Wywiad i kontrwywiad wojskowy II RP, t. 1, red. T. Dubicki, Łomianki 2010, s. 385, przyp. 144.

135 М. Бржестовский, Свидание с родиной, [в:] От зарубежья до Москвы. Нароно-Трудовой Союз (НТС) в воспоминаниях и документах 1924-2014, ред. В. Сендеров, Москва 2014, s. 95.

136 Ł. Ulatowski, Niezbrzycki. Wybrane aspekty biografii wywiadowczej kierownika Referatu „Wschód', s. 26, https://www.academia.edu/3459067/\%C5\%81ukasz_Ulatowski_Niezbrzycki_wybrane_ aspekty_biografii_wywiadowczej_kierownika_Referatu_Wsch\%C3\%B3d_(dostęp: 23.04.2015).

137 Ibidem. 
Państwowym Archiwum Wojskowym rzeczywiście jest trudno dostępna; w takim wypadku jednak tym bardziej warto sięgnąć do dostępnych relacji rosyjskich oraz rosyjskiej prasy emigracyjnej ${ }^{138}$.

Drugą osobą koordynującą współpracę z Rosjanami był Henryk Suchenek-Suchocki. Mimo że w latach trzydziestych nie był już pracownikiem Oddziału II, wciąż mógł z nim utrzymywać kontakt i koordynować niejako z jego ramienia działania prowadzone wobec Rosjan w ramach Wydziału Narodowościowego MSW, którego był szefem ${ }^{139}$.

Początek działalności nowopokoleńców w Polsce należy datować na przełom lat dwudziestych i trzydziestych, lecz pierwsze poświadczone w źródłach rozmowy między Oddziałem II a przedstawicielem Biura Wykonawczego NTS Michaiłem Gieorgijewskim miały miejsce dopiero $\mathrm{w}$ drugiej połowie lat trzydziestych ${ }^{140}$. Współpraca NSRM/NTS z Oddziałem II została zapoczątkowana nie w 1937 r., za pośrednictwem wywiadu japońskiego, jak twierdzą w swojej pracy Gribkow, Żukow i Kowtun, lecz - jak wykazaliśmy - już na początku lat trzydziestych, bez japońskiego pośrednictwa ${ }^{141}$. Wśród nowopokoleńców zaangażowanych we współpracę z Polakami ze strony rosyjskiej najważniejszymi postaciami byli: szef polskiego oddziału NTS Aleksandr Würgler, członek Biura Wykonawczego NTS Władimir Brandt, prezes ROM Nikołaj Szumlin oraz nadzorujący przerzut działaczy do ZSRS, członek kierownictwa NTS Gieorgij Okołowicz. Niejasna pozostaje kwestia szkoły dla członków NTS zorganizowanej przy wsparciu Oddziału II oraz funkcjonującego przy niej sztabu, którego szefem był Okołowicz („штаб похода

138 Do tej pory autorowi udało się ustalić dziesięć rosyjskich relacji zawierających informacje o działalności NTS w Polsce, autorstwa: Jewgienija Diwnicza, Wiktora Bajdałakowa, Michaiła Brżestowskiego, Michaiła Gieorgijewskiego, Aleksandra Kołkowa, Georgija Okołowicza, Borisa Prianisznikowa, Arkadija Stołypina, Jarosława Trusznowicza i Siergieja Wojciechowskiego.

139 AIPN BU, 2386/16886, Informacja..., k. 68.

140 „Powiedział mi [Gieorgijewski], że NTS cieszy się poparciem rządu polskiego. Dzięki pomocy Polaków w okolicach Wilna zostało otwarte okno, którym nasi ludzie przedostawali się do ZSRR”, A. Stołypin, op. cit., s. 199-200; „Он тогда [koniec 1938 r.] обьезжал отделы Союза в разных странах и из Варшавы приехал в Берлин”, „Генералный секретар ИБ проф. М.А. Георгиевский договорился с Польяками о совместной работе на советско-полской границе”, Б. Прянишников, op. cit., s. 90; „Георгиевский поддерживал связь с рядом иностранных разведок, в частности с японской и польской разведками, которые финансировали НТСНП, снабжали оружием, фиктивными документами и организовывали переброску агентов для проведения шпионской и террористической деятельности. По этой шпионской и подрывной работе Георгиевский был тесно связан с японскими военными атташе в Варшаве и в Берлине генералами Савада и Кавабэ и начальником восточного отдела Польского Генерального Штаба Незбра-жицким. [...] В 1937 г. в СССР были переброшены с террористическими заданиями два члена НТС Околович Г.С. и Колков А.Г”, Приговор Военной Коллегии Верховного Суда Союза ССР, w: Политическая история..., http://www.russky.com/history/library/emigration/ emigration3.htm\#290 (dostęp: 27.04.2015); zob. przyp. 108.

${ }^{141}$ И. Грибков, Д. Жуков, И. Ковтун, ор. cit., s. 89. Autorzy ci nie odnoszą się do wcześniejszej działalności nowopokoleńców w Polsce. 
HCHП”) ${ }^{142}$. Trudno sprecyzować, gdzie mogła się ona mieścić i czy służyła jedynie szkoleniu członków NTS (szkolono w niej członków organizacji z całej Europy). Jak do tej pory, udało nam się dotrzeć tylko do jednej bardziej szczegółowej relacji, która opisuje przebieg takiego kursu. Michaił Brżestowskij przybył do Polski z Niemiec latem 1939 r. na polecenie Wiktora Bajdałakowa, w celu odbycia kursu; po jego ukończeniu miał zostać przerzucony do ZSRS. Kurs trwał dwa miesiące (czerwiec-lipiec), w czasie których uczono m.in. odpowiedniego zachowania, topografii rejonów przygranicznych, geografii Rosji, sieci kolejowej, szyfrowania korespondencji, fotografii, struktury partii i aparatu państwowego, otwierania zamków, obsługi broni krótkiej, sowieckiej terminologii i życia codziennego (wykorzystywano materiały, które wytworzył Okołowicz po powrocie ze swojej pierwszej misji w ZSRS w $1938 \mathrm{r}$.), organizowano również marsze kondycyjne 60-70 km ${ }^{143}$. Oprócz oficerów Oddziału II wykładali Gieorgij Okołowicz, Szura Kołkow, kornet Aleksandr Czuprunow oraz, jak należy sądzić, Władimir Brandt. Wywiad polski ułatwiał także przerzut członków NTS do ZSRS oraz fabrykował dla nich dokumenty ${ }^{144}$. Interesujące jest, że poprzez Stołypina, który odbył latem $1939 \mathrm{r}$. misję do Polski, centrala NTS starała się ostrzec Polaków przed uderzeniem ze wschodu: „Kiedy wyłożyłem cel mojej podróży (uprzedzenie Polaków o niebezpieczeństwie grożącym im ze strony sowieckiej), oświadczył mi z powagą [Würgler], że niczego nie osiągnę. Mając wiernych przyjaciół w polskim sztabie głównym (jak pułkownik Wraga, którego następnie poznałem, szef sekcji rosyjskiej), próbował już otworzyć im oczy" ${ }^{145}$. Przyjmując, że rzeczywiście Rosjanie przedstawili dowody na agresywne zamiary ZSRS względem Polski, wątpliwe jest, by Niezbrzycki je zbagatelizował ${ }^{146}$. Wydaje się, że do blokady informacji lub błędnej interpretacji doszło na wyższym szczeblu. Dużą rolę w wyjaśnieniu tej kwestii mogłoby odegrać poznanie stosunku wicedyrektora Departamentu Polityczno-Ekonomicznego MSZ i naczelnika Wydziału Wschodniego MSZ Tadeusza Kobylańskiego (według Pawła Wieczorkiewicza, powołującego się na rosyjskie opracowania, od $1937 \mathrm{r}$.

${ }^{142}$ Первое приложение [relacja, z wyprawy do ZSRS A. Kołkowa], w: А.П. Столыпин, На службе России. Очерки по истории НТС, 1986, http://ntsrs.ru/content/prilozheniya-k-tretey-glave (dostęp: 27.04.2015). Według relacji Okołowicza, na którą powołują się zarówno Prianisznikow, jak i Stołypin, w 1938 r. wysłano z terenu Polski sześciu przeszkolonych działaczy jugosłowiańskiego oddziału NTS (trzech zginęło, jeden nie przedarł się przez granicę, tylko dwóch - G. Ookołowicz i A. Kołkow - odbyło kilkumiesięczną podróż po ZSRS); następne trzy grupy wysłano w sierpniu 1939 r.; Б. Прянишников, op. cit., s. 100-101; М. Бржестовский, op. cit., s. 95.

143 Ibidem, s. 92-93.

144 Й. Дивнич, НТС..., s. 36.

145 A. Stołypin, op. cit., s. 209.

146 Według przytoczonej przez Bączkowskiego relacji płk. Romana Umiastowskiego, Niezbrzycki miał być wezwany 6 września 1939 r. do szefa sztabu gen. Wacława Stachiewicza, któremu zameldował „że Rosja niewątpliwie wystąpi”, W. Bączkowski, Jerzy Niezbrzycki (R. Wraga) 1902-1968, „Niepodległość” 23 (1990), s. 120. 
agenta Razwiedupru ${ }^{147}$ do działalności NTS-u. Jego krytyczna ocena działań tej organizacji mogłaby wskazywać, że to on „blokował” informacje oraz potwierdzałaby tezę o jego agenturalnych związkach z Sowietami.

Współpraca polsko-rosyjska miała również trwać w Rumunii, m.in. za pośrednictwem Gieorgija Okołowicza, Michaiła Olgskiego, kpt. Bronisława Eliaszewicza ${ }^{148}$, i kpt. Jerzego Niezbrzyckiego, który miał towarzyszyć ewakuowanym członkom NTS w drodze do Rumunii, a potem także spotkać się z samym Władimirem Bajdałakowem w Belgradzie ${ }^{149}$. Warto wspomnieć, że według jednej z relacji NTS miał ponieść ciężkie straty w wyniku kampanii wrześniowej, rzekomo już wtedy przystępując do agitacji wśród czerwonoarmistó $w^{150}$. W czasie okupacji warszawski NTS pod przywództwem Würglera miał współpracować z polskim podziemiem ${ }^{151}$, prowadzić podwójną grę z Niemcami ${ }^{152}$, a także działania przeciwko Związkowi Sowieckiemu ${ }^{153}$,

147 P. Wieczorkiewicz, Łańcuch śmierci. Czystka w Armii Czerwonej 1937-1939, Warszawa 2001, s. 687.

148 Kpt. B. Eliaszewicz, we wrześniu 1939 r. przydzielony do Ref. „Wschód”, przeszedł do Rumunii, pracował w ekspozyturze „R”, w Ref. Organizacyjnym, a następnie Ref. Wywiadowczym, w latach 1941-1943 kierował placówką nr 1 „Tandara” w Bukareszcie; Załącznik do sprawozdania..., s. 386, przyp. 149.

149 „Падение Польши не прервало сотрудничества поляков с «бледналицыми». Маёр Бронислав Николай Ильяшевич [kpt. Eliaszewicz] был принят японским военным атташе в Букаресте на службу, а вместес ним - Околович и Ольгский. Было решено возобновить отправки членов Союза в Россию, на сей раз путем перебраски через румыно-советскую границу”. Autor twierdzi również, że w 1940 r. kpt. Eliaszewicz wystawił mu polski paszport; Б. Прянишников, op. cit., s. 137 і 139; „В огне военных событий, до занятия немцами Польши, некоторые ответственные члены Союза пробились с польской территории с отступающими поляками в Румынию", А.П. Столыпин, На службе..., http://ntsrs.ru/content/glava-4nachalo-krupnyh-ispytaniy (dostęp: 23.04.2015); М. Бржестовский, op. cit., s. 95.

150 „Там НТС и понес чувствительные потери в 1939 году, когда в Польшу двинулись части Красной армии. Некоторые члены Союза, не маскируясь, начали открыто вести пропаганду среди бойцов РККА и в конце концов были захвачены. Другие не сумели уйти в подполье, третьи попали в руки органов по доносам просоветски настроенных земляков. Но многие все-таки перебежали в зону немецкой оккупации. А небольшой части членов НТС удалось под видом рабочих пробраться в СССР, - о чем руководство узнало только в 1941 году, во время немецкого наступления", Я. Трушнович, К истории...

151 „Многие [działacze NTS] имели липовые документы, которые выдавал контактировавший как с немцами, так и с польским подпольем в Варшаве, член Совета НТС А. Э. Вюрглер”, Б. Пушкарев, НТС. Мьсль и дело. К 80-летию НТС и 65-летию издательства „Посев", „Новый Журнал” 262 (2011), http://magazines.russ.ru/nj/2011/262/pu18.html (dostęp: 22.04.2015). Członkowie NTS mieli wziąć udział również w powstaniu warszawskim; Т.Д. Исмагулова, op. cit., s. 351. Warto dodać, że w tłumieniu powstania warszawskiego nie brali udziału żołnierze gen. Andrieja Własowa, z którymi współpracowała część członków NTS, lecz niezwiązane z nią oddziały Rosyjskiej Wyzwoleńczej Armii Ludowej Bronisława Kamińskiego; W. Sukiennicki, op. cit., s. 15.

152 С.Л. Войцеховский, op. cit.

${ }^{153}$ Należy podkreślić, że odbywało się to zgodnie z złożeniami ideologicznymi zawartymi w wykładzie wygłoszonym na początku 1939 r. przez przewodniczącego NTS Wiktora Bajdałakowa: „Ни со Сталиным, ни с иностранными завоевателями, а со всем русским народом... 
w efekcie czego zostało aresztowanych ${ }^{154}$ lub poległo wielu jego członków, w tym Würgler i Brandt ${ }^{155}$.

\section{Podsumowanie}

Akcja prometejska była jednym z czynników osłabiających chęć współpracy Rosjan z Polakami. Wyjątek stanowiło wąskie grono współpracowników nieocenionego dla promowania idei porozumienia polsko-rosyjskiego Dimitrija Fiłosofowa - byli oni jednymi z niewielu Rosjan utrzymującymi kontakty z narodami prometejskimi ${ }^{156}$. Rosjanie deklarujący chęć współpracy z innymi narodami byłego imperium Romanowów stanowili margines rosyjskiej sceny politycznej ${ }^{157}$. Najbardziej liberalni z nich (poza wspomnianym Fiłosofowem), dopuszczali jedynie możliwość ustanowienia autonomii dla narodów nierosyjskich; rzadziej niż inni kwestionowali granicę Polski, a po II wojnie światowej również państw bałtyckich.

$\mathrm{Z}$ polskiego punktu widzenia działalność prometejska nie musiała wykluczać wspierania rosyjskiego ruchu antykomunistycznego; faktem jest jednak, że większość zaangażowanych prometeistów raczej ograniczała się do monitorowania działań rosyjskich organizacji aniżeli podejmowała współpracę z nimi. Współpraca z Rosjanami od czasu afery „Trust” uległa osłabieniu i przemodelowaniu. Prowadząc infiltrację rosyjskich środowisk Oddział II wszedł w kontakt z ruchem nowopokoleńców. W drugiej połowie lat trzydziestych nastąpiła intensyfikacja współpracy z tym ruchem, która nasilała się aż do wybuchu wojny. Nie zakładała ona pozyskiwania informacji o charakterze strategicznym (z centrów władzy), lecz miała na celu dostarczenie ogólnych informacji o Związku Sowieckim, który w końcu lat dwudziestych był już bardzo szczelnie odizolowany od reszty świata (być może celem miało być

Национальная Революция есть сегодня первое задание оборона страны. Она останется и тогда, когда вспыхнет война... Россию спасет русская сила, на русской земле", суt. za: Б. Прянишников, op. cit., s. 112.

154 Wielu z nich, latem 1944 r., aresztowało gestapo; J.J. Stephan, The Russian Fascists Tragedy and Farce in Exile, 1925-1945, London 1978, s. 30.

155 Przeżył ich znajomy, Gieorgij Sokołow, od 1960 r. sprawujący funkcję przewodniczącego Zarządu Głównego Rosyjskiego Towarzystwa Kulturalno-Oświatowego; P. Mitzner, Warszawski „Domek w Kołomnie"..., s. 59.

156 Fiłosofow był na 9. rocznicy powołania armii URL w maju 1927 r. i corocznym balu ukraińskich studentów w lutym 1926 r. - wydarzeniach skupiających działaczy prometejskich; E. Wiszka, op. cit., s. 193-194, 209.

157 Drastycznym przykładem „nawrócenia” z drogi współpracy z innymi narodami był Borys Sawinkow, który $\mathrm{w}$ swoich listach $\mathrm{z}$ Łubianki spowiadał się, tłumacząc motywy przejścia na stronę bolszewików (możliwe, że użyto przeciwko niemu różnych metod śledczych, by „wyprodukował”, na potrzeby Związku Sowieckiego, podobnie jak Jurko Tiutiunnyk, materiały przekreślające sens walki z władzą komunistyczną. Nawet przy niewielkiej wiarygodności tych materiałów można sądzić, że odzwierciedlają one problem posługiwania się przez bolszewików, przy pozyskiwaniu emigrantów do współpracy, argumentami o charakterze patriotycznym oraz nacjonalistycznym); Б. Савинков - Д. Философову, 20.12.24 г. Москва, w: Борис Савинков на Лубянке..., s. 143. 
również zbudowanie zrębów siatki dywersyjno-wywiadowczej na wypadek wojny z ZSRS). Na arenie wewnętrznej współpraca z Rosjanami służyła wspieraniu spośród nich osób lojalnych wobec władzy, w wyniku czego na początku lat trzydziestych osiągnięto efekt konsolidacji ruchu rosyjskiego wokół państwa polskiego.

Osobą szczególnie aktywnie współpracującą z emigracją rosyjską na gruncie polityki wewnętrznej był Tadeusz Hołówko, wyróżniający się pod tym względem spośród innych prometeistów; w sprawy mniejszości rosyjskiej zaangażowani byli Bronisław Pieracki oraz szczególnie Henryk Suchenek-Suchocki. Z kręgów Oddziału II takimi postaciami byli płk Tadusz Schaetzel i kpt. Jerzy Niezbrzycki, który według Włodzimierza Bączkowskiego, zaczął z czasem uważać, że „Upadek Moskwy jest możliwy tylko w razie oporu «w pierwszym rzędzie narodu rosyjskiego jako najliczniejszego. Naród rosyjski musi stać się sojusznikiem zarówno Polaków jaki i Ukraińców»"158. Być może do sformułowania tego poglądu przyczyniła się jego współpraca z nowopokoleńcami, na co mogłaby wskazywać również cytowana wyżej relacja Brżestowskiego.

Niebagatelną rolę w nawiązaniu kontaktu z nowopokoleńcami mogło odegrać ich negatywne nastawienie zarówno do III Rzeszy, jak i ZSRS, co pozwalało na znalezienie wspólnego mianownika z państwem polskim.

Wciąż bez odpowiedzi pozostaje pytanie, jaki był główny cel współpracy z członkami NTS? Czy chodziło jedynie o przeciwstawienie antypolskim ruchom młodzieżowym propolskiego związku, pozyskiwanie informacji oraz ewentualną dywersję, nie tylko w zachodniej Rosji, ale również na Dalekim Wschodzie ${ }^{159}$, czy również o stworzenie stałego lobby propolskiego oraz grupy, która mogłaby zostać użyta na wypadek wojny z ZSRS?

Kolejną kwestią wymagającą zbadania jest pytanie, na ile ruch nowopokoleńców był inspirowany ze strony Oddziału II, a na ile była to naturalne współpraca, której podjęcie było suwerenną decyzją władz NSRM. Pozyskanie tego ruchu pozwoliło na wykreowanie wśród części młodzieży emigracyjnej dobrego wizerunku Polski, a także - poprzez rozwój organizacji - wpłynęło na osłabienie wpływów negatywnie nastawionych do państwa polskiego, prosowieckich oraz proniemieckich organizacji młodzieżowych rywalizujących z NTS, który wyszedł z niej zwycięsko i jako jedyny nieustannie powiększał swoje struktury, kontynuując działalność po 1945 r., aż do upadku ZSRS.

Należy podkreślić, że poza NTS sondowano również inne organizacje związane z ruchem eurazjatyckim, takie jak „Impierskij Sojuz” oraz znanych działaczy rosyjskich takich jak prof. Piotr Struwe, czy w Polsce Siergiej Wojciechowskij i Andriej Surkow.

Decyzja o podjęciu współpracy z NTS okazała się znakomitą „inwestycją” Oddziału II, nawet jeśli nikt spośród kierujących sprawą nie miał takich intencji. Dowodem na to jest lojalność, jaką okazali względem Polaków członkowie NTS

158 W. Bączkowski, op. cit., s. 118.

159 И. Грибков, Д. Жуков, И. Ковтун, op. cit., s. 92. 
we wrześniu 1939 r., a także w czasie II wojny światowej, jak również po niej, o czym dowiadujemy się z licznych wspomnień.

Współpraca nawiązana w latach trzydziestych XX w. procentuje do dzisiaj, jako że NTS przetrwał do upadku Związku Sowieckiego i rozwinął swoją działalność w kraju. Na jego konto można zaliczyć nie tylko akcje promujące idee emigracji rosyjskiej, jak film „Admirał”, ale również odczyty na temat popełnionych przez władze ZSRS zbrodni, w tym mordu na polskich oficerach w Katyniu ${ }^{160}$.

\section{Only Prometheism? Polish State Policy towards Chosen Russian Exiles 1926-1935}

\section{Abstract}

The article spans the period of 1926-1935, but the presentation of the Polish state policy towards chosen Russian exiles is set in context of the Polish-Russian cooperation from 1920 to the 1926 May Coup and concludes with an epilogue about Jerzy Niezbrzycki's cooperation with the members of the Polish branch of the NTS (The National Alliance of Russian Solidarists) in the second half of the 1930s. The author explores the questions of attitudes of the Second Division of the General Staff of the Polish Army and the Ministry of Internal Affairs (occasionally engaged at the same time in Promethean work and contacts with leading members of Russian emigrants in Poland and abroad) towards the Russian emigration. Thus, the article is to answer the questions of the significance of this diaspora to the Polish authorities and of the mechanisms of enlisting their support for the Polish state.

The author has reached following conclusions: from the Polish perspective, Promethean activities did not automatically exclude the support for the Russian anti-communist movement, although in fact in the case of a majority of Prometheans it was limited to monitoring of activities of Russian organisations rather than cooperating with them. Contrary to opinions of some researchers, the cooperation with the Russians was not broken after the MOCR-Trust was revealed at the turn of the 1927, but was re-modelled. Often, the purpose of maintaining contacts with the Russians was to replace the activists inconvenient to the authorities with those who were loyal to them; such a policy brought about in the early 1930s the effect of consolidation of the Russian movement around the Polish state, and minimalised German and Soviet impact on it. The study is based on the analysis of the Russian press, memories, published documents and correspondence, as well as materials hold in the Central Archives of Modern Records in Warsaw, Archives of the Institute of National Remembrance and the online collection of the Józef Piłsudski Institute in New York and International Institute of Social History at Amsterdam.

\section{Разве только прометеизм? Политика Польского государства по отношению к выбранным кругам российской эмиграции в 1926-1935 гг.}

\section{Аннотация}

Статья охватывает период 1926-1935 гг., но ей предшествует история польско-российского сотрудничества с 1920 г. по Майский переворот, а завершает эпилог на тему сотрудничества Ежи Незбжицкого с членами польского отделения НТС во второй половине

160 http://magazines.russ.ru/nj/2011/262/pu18.html (dostęp: 6.05.2015). 
30-х гг. В ней были затронуты вопросы, касающиеся отношения к российской эмиграции работников II отделения Главного штаба, а также Министерства внутренних дел (иногда одновременно вовлеченных в прометейскую работу и контакты с ведущими представителями российской эмиграции в Польше и за рубежом). Тем самым, этот текст должен быть ответом на вопросы о значении этой диаспоры для польских властей и о механизмах приобретения их для Польского государства.

Автор м. пр. пришел к следующим заключениям - с польской точки зрения, прометейская деятельность не должна была исключать поддержку российского антикоммунистического движения, хотя, действительно, в случае большинства вовлеченных прометеистов, сводилась, скорее, к наблюдению за действиями российских организаций, чем сотрудничеству с ними. Вопреки мнениям некоторых исследователей, сотрудничество с русскими не было расторгнуто после разоблачения на рубеже 1926 и 1927 г. аферы под кодовым названием Tpecm (Trust), но подверглось преобразованию. Поддерживание контактов с русскими часто имело целью замену неудобных российских деятелей лояльными к власти; в результате так ведомой политики, в начале 30 -х годов был достигнут эффект сплочения российского движения вокруг Польского государства, сводя в нем к минимуму немецкое и советское влияние.

В данной работе были проанализированы российская пресса, воспоминания, изданные документы и переписка, а также документы из Архива новых актов, Архива ИНП, онлайн-коллекции Института им. Юзефа Пилсудского в Нью-Йорке и амстердамского Международного института социальной истории.

\section{Bibliografia}

\section{Archiwalia}

Archiwum Akt Nowych, Warszawa, Ministerstwo Spraw Wewnętrznych

Archiwum Instytutu Pamięci Narodowej, Warszawa, BU 1572/1017, Pracownicy ekspozytury nr 2 Oddziału II Sztabu Głównego. Komunikat Nr 5 Głównego Zarządu Informacji MON; BU 1572/1165, Oddział II Sztabu Głównego Wojska Polskiego Referat „Wschód” w latach 1929-1939 [...]. Opracowanie płk. Gajewskiego z Głównego Zarządu Informacji MON, wykazy placówek zagranicznych; BU 2602/1440, Zarząd II Sztabu Generalnego WP w Warszawie. Teczka I Działalność Oddziału II Sztabu Głównego w latach 33-39 raporty; BU, 2386/16886, Szefostwo WSW 1960-1963.

Instytut im. Józefa Piłsudskiego w Nowym Jorku, Ukraińska Misja Wojskowa w Polsce (kolekcja online).

International Institute of Social History, Amsterdam, Boris Viktoroviĉ Savinkov Papers (kolekcja online).

\section{Prasa}

„Меч”, Warszawa 1934-1935.

„Молва”, Warszawa 1932-1934.

„Новая Россия”, Wilno 1926-1928.

„Свобода”, Warszawa 1920.

„Виленское утро”, Wilno 1926.

„За Свободу!”, Warszawa 1920-1932. 


\section{Źródła publikowane i opracowania:}

Backer R., Międzywojenny eurazjatyzm. Od intelektualnej kontrakulturacji do totalitaryzmu?, Łódź 2000.

Bączkowski W., Jerzy Niezbrzycki (R. Wraga) 1902-1968, „Niepodległość” 23 (1990).

Besançon A., Święta Ruś, Warszawa 2012.

Borzęcki J., Pokój ryski 1921 roku i kształtowanie się międzywojennej Europy Wschodniej, Warszawa 2012.

Bruski J.J., Między prometeizmem a Realpolitik. II Rzeczpospolita wobec Ukrainy sowieckiej 1921-1926, Kraków 2010.

Czapski J., Świat w moich oczach, Ząbki-Paris 2001.

Czapski J., Wyrwane strony, op. Joanna Pollakówna, Warszawa 1993.

Dokumenty $i$ materiały do historii stosunków polsko-radzieckich, t. 3, red. N. Gąsiorowska-Grabowska, I.A. Chrienow; t. 4, red. T. Cieślak, I.A. Chrienow, Warszawa 1964-1965.

Dokumenty $z$ dziejów polskiej polityki zagranicznej 1918-1939, red. T. Jędruszczak, M. Nowak-Kiełbikowa, t. 1, Warszawa 1989.

Dryblak Ł., Inspiracja i formy współpracy polskich instytucji państwowych $z$ wydawcami i redakcjami pism rosyjskich w latach 1919-1935 - zarys problematyki, „Dzieje Najnowsze” 48 (2016), nr 1.

Drymmer W.T., Trust, „Kultura” 11 (Paryż 1965).

Durrant J.S., B. Sawinkow w Warszawie - z pamiętników D. W. Fiłosofowa oraz Zapomniany Warszawianin, mps w archiwum „Kultury” w Maisons-Laffitte (kserokopie udostępnione autorowi dzięki uprzejmości prof. Andrzeja Nowaka).

Gippius Z., Dzienniki petersburskie. Dziennik warszawski, tłum. i op. H. Chłystowski, Warszawa 2010.

Heller M., List Borysa Sawinkowa do marszałka Piłsudskiego, w: Sowietskij Sojuz. Wybór, Wrocław 1989, s. 79-90.

Karpus Z., Wschodni sojusznicy Polski w wojnie 1920 roku. Oddziały wojskowe ukrainskie, rosyjskie, kozackie i białoruskie w Polce w latach 1919-1920, Toruń 1999.

Kornat M., Idea prometejska a polska polityka zagraniczna (1921-1939/1940), w: Ruch prometejski $i$ walka o przebudowę Europy Wschodniej (1918-1940), red. M. Kornat, Warszawa 2012.

Kornat M., Instytut Naukowo-Badawczy Europy Wschodniej w Wilnie (1930-1939) i jego wkład w rozwój polskiej sowietologii, „Kwartalnik Historyczny” 107 (2000), nr 3.

Kornat M., Tadeusz Schaetzel (1891-1971) nota biograficzna, „Pressje” 2010, nr 22-23.

Kropp P., Sekrety wywiadu francuskiego, Warszawa 1999.

Libera P., Ewolucja ruchu prometejskiego w okresie międzywojennym, w: Ruch prometejski i walka o przebudowe Europy Wschodniej (1918-1940), red. M. Kornat, Warszawa 2012.

Listy Dymitra Fiłosofowa do Mariana Zdziechowskiego, op. P. Ławriniec, „Zeszyty Historyczne” 168 (Paryż 2008).

Materski W., Na widecie. II Rzeczpospolita wobec Sowietów 1918-1943, Łódź 2005.

Mereżkowski D., Józef Piłsudski, „Twórczość” 52 (1996), nr 4.

Michniewicz W., Wielki bluff sowiecki, Chicago 1991.

Mitzner P., Warszawski „Domek w Kołomnie”, Warszawa 2014.

Mitzner P., Warszawski krag Dymitra Fiłosofowa, Warszawa 2015.

Nowak A., Dymitr Fiłosofow: dyskusja z polska „mickiewiczologia” czy z polskim kompleksem?, $\mathrm{w}$ : Akademie nauk, uniwersytety, organizacje nauki, polsko-rosyjskie relacje $w$ sferze nauki XVIII-XX w., red. L. Zasztowt, Warszawa 2013.

Nowak A., Jak rozbić rosyjskie imperium. Idee polskiej polityki wschodniej (1733-1921), Warszawa 1991. 
Nowak A., Polska i trzy Rosje. Studium polityki wschodniej Józefa Piłsudskiego (od kwietnia 1920 roku), Kraków 2001 (wyd. uzup. 2014).

Paduszek K., Polski wywiad wojskowy na Rosje Sowiecka/Związek Sowiecki w latach 1921-1927, Warszawa 2014, mps pracy doktorskiej, Biblioteka Instytutu Historycznego Uniwersytetu Warszawskiego.

Pipes R., Struve. Liberal on the Right, 1905-1944, London 1980.

Polityka narodowościowa władz polskich wobec emigracji i mniejszości rosyjskiej w latach 19261935. Wybór dokumentów, oprac. Ł. Dryblak, „Przegląd Wschodni”, 14 (2015), nr 1.

Rosyjski łącznik Naczelnika - wybór listów Karola Wędziagolskiego do Piotra Wandycza, op. A. Nowak, „Arcana” 70/71 (2006).

Sasiedzi wobec wojny 1920 roku, oprac. J. Cisek, Londyn 1990.

Skrunda W., Rosyjska „Mniejszościowa” Organizacja Młodzieżowa w Polsce międzywojennej (ROM). Okoliczności powstania, „Studia Rossica” 5 (1997).

Snyder T., Tajna wojna Henryk Józewski i polsko-sowiecka rozgrywka o Ukrainę, Kraków 2008 .

Spence R.B., Renegade on the Left, New York 1991.

Stanisław Patek. Raporty i korespondencja z Moskwy (1927-1932), oprac. M. Gmurczyk-Wrońska, Warszawa 2010.

Stanisławski W., „Rycerz przegranej sprawy”? Kontakty Dymitra Fiłosofowa z polskimi elitami kulturalnymi, w: Emigracja rosyjska losy i idee, red. r. Backer, Z. Karpus, Łódź 2002.

Stanisławski W., Myśl polityczna emigracji rosyjskiej w II Rzeczpospolitej: interpretacje przeszłości i koncepcje polityczne, mps pracy doktorskiej, Biblioteka Instytutu Historycznego Uniwersytetu Warszawskiego.

Stephan J.J., The Russian Fascists tragedy and Farce in Exile, 1925-1945, London 1978.

Stołypin A., Cesarstwo i wygnanie, tłum. T. Hertz, Warszawa 1998.

Sukiennicki W., Trzydzieści lat emigracji rosyjskiej, Londyn 1949.

Ulatowski Ł., Niezbrzycki - wybrane aspekty biografii wywiadowczej kierownika Referatu „Wschód”, w:http://www.academia.edu/3459067/Lukasz_Ulatowski_Niezbrzycki_wybrane_ aspekty_biografii_wywiadowczej_kierownika_Referatu_Wschod.

Wędziagolski K., Pamiętniki, wojna i rewolucja, kontrrewolucja, bolszewicki przewrót, warszawski epilog, Warszawa 2007.

Wieczorkiewicz P., Łańcuch śmierci. Czystka w Armii Czerwonej 1937-1939, Warszawa 2001. Wiszka E., emigracja ukrainska w Polsce 1920-1939, Toruń 2004.

Załącznik do sprawozdania $z$ działalności Oddziału II Sztabu Głównego, oprac. T. Dubicki, A. Suchcitz, w: Wywiad i kontrwywiad wojskowy II RP, t. 1, red. T. Dubicki, Łomianki 2010, s. 342-393.

Байдалаков В.М., Да возвлечится Россия. Да гибнут наши имена... Воспоминания председатела НТС 1930-1960 г2., Москва 2002

Борис Савинков на Лубянке. Документы, ред. А.Л. Литвин, Москва 2001.

БржестовскийМ. , Свидание с родиной, [в:] От зарубежья до Москвы. Нароно-Трудовой Союз (НТС) в воспоминаниях и документах 1924-2014, ред. В. Сендеров, Москва 2014, с. 90-104.

Войцеховский С.Л., Эпизоды, London-Kanada 1978, http://www.dk1868.ru/history/voytzexov. htm\#z151 (dostęp: 14.01.2014).

Грибков И.В.,. Жуков Д.А, Ковтун И.И., Особый штаб „Россия”, Москва 2011.

Дивнич Е., Нам пора объясниться!, New York 1968.

Из переписки Д.В. Филособова. 1920-1932, „Наше Наследие” 63-64 (2002), http://www. nasledie-rus.ru/podshivka/6407.php (dostęp: 14.01.2015).

Из протоколов допросов лидера Национально-Трудового Союза Нового Поколения М.А. Георгиевского, w: Политическая история русской эмиграции 1920-1940 г2. 
Документы и материалы, ред. А.Ф. Киселев, Москва 1999, http://www.russky.com/ history/library/emigration/emigration3.htm\#290 (dostęp: 27.04.2015);

Relacja Borysa Kowerdy, http://zhurnal.lib.ru/g/gorbunow_g_a/koverda.shtml (dostęp: 5.05.2015).

Исмагулова Т.Д., Русская эмиграция в Польше (Владимир Бранд - поэт и воин „русской Варшави”), w: Зарубежная Россия 1917-1939 г2., ред. В. Ю. Черняев, Санкт-Петербург 2003.

Окороков А.В., Русская эмиграция, Москва 2003.

Прянишников Б., Новопоколенцы, Merylend 1986.

Сочинения русского периода, t. 1, Стихотворения и поэмьь, ред. Л. Флейшман, Москва 2011.

Столыпин А.П., На службе России. Очерки по истории НТС, Frankfurt am Main 1986, http://ntsrs.ru/content/p-stolypin-na-sluzhbe-rossii (dostęp: 30.05.2014).

Струве П.Б., Дневник Политика (1925-1935), Москва-Париж 2004.

Трушнович Я., К истории Нородно-Трудового Союза, „Посев” 7 (2000), http://www.posev. $\mathrm{ru} /$ files/nts-about/ne7006.htm (dostęp 9.04.15).

Флейшман Л., Абызов Ю., Равдин Б., Русская печать в Риге: из истории газетьь «Сегодня» 1930-х годов, t. 1-5, Stanford 1997.

Łukasz Dryblak, doktorant w Instytucie Historii Polskiej Akademii Nauk. Zainteresowania badawcze: stosunki polsko-rosyjskie, emigracja rosyjska, historia wojskowości, polityka narodowościowa II Rzeczypospolitej (lukaszdryblak7@wp.pl).

Eukasz Dryblak, PhD student in the Institute of History of the Polish Academy of Sciences. Research interests: Polish-Russian relations, Russian exile, military history, ethnic policy of the Second Polish Republic (lukaszdryblak7@wp.pl). 